\title{
Exploring the links between forest transition and landscape changes in the Mediterranean. Can forest recovery lead to lower landscape quality?
}

Joan Marull ${ }^{a,}$, Iago Otero ${ }^{\mathrm{b}}$, Constantí Stefanescu ${ }^{\mathrm{c}, \mathrm{d}}$, Enric Tello ${ }^{\mathrm{e}}$, Marta Miralles ${ }^{\mathrm{f}}$, Francesc Coll $^{\mathrm{a}}$, Manel Pons ${ }^{\mathrm{a}}$, Giovanna L. Diana ${ }^{\mathrm{a}}$

a Barcelona Institute of Regional and Metropolitan Studies (IERMB), Building MRA, Autonomous University of Barcelona, 08193 Bellaterra, Spain

b Institute of Environmental Science and Technology (ICTA), Building C, Autonomous University of Barcelona, 08193 Bellaterra, Spain

${ }^{c}$ Catalan Butterfly Monitoring Scheme, Museu de Ciències Naturals de Granollers, 08402 Granollers, Spain

${ }^{\mathrm{d}}$ Global Ecology Unit, Centre for Ecological Research and Forestry Applications, Autonomous University of Barcelona, 08193 Bellaterra, Spain

e Department of Economic History and Institutions, University of Barcelona, Faculty of Economics and Business, Diagonal 690, 08034 Barcelona, Spain

${ }^{\mathrm{f}}$ Ajuntament de Sant Celoni, Plaça de la Vila, 1. 08470 Sant Celoni, Spain

* Corresponding author: Tel.:+34 93 5868880; Fax: 3493 5814433; Email: joan.marull@ uab.cat 


\section{Abstract}

A growing number of studies argue that forest transition should be enhanced by policymakers given its potential benefits, for instance in slowing climate change through carbon sequestration. Yet the effects of forest transition in landscape and biodiversity remain poorly understood. In this paper we explore the relationships between the forest transition experienced by one Mediterranean mountain area, and the landscape changes occurred therein. Historical land-use maps were built from cadastral cartography $(1854 ; 1956 ; 2012)$. Metrics on land-cover change, landscape structure, and landscape functioning were calculated. Multiyear data on butterfly assemblages from two transects was used as indicator of land-use change effects in biodiversity (1994-2012). Results show a forest expansion process in former cereal fields, vineyards and pasturelands along with rural out-migration and land abandonment. Such forest transition involved large changes in landscape structure and functioning. As peasant management of integrated agrosilvopastoral systems disappeared, landscape became less diverse. Even if forest area is now larger than in mid- $19^{\text {th }}$ century, ecological connectivity among forest areas did not substantially improve. Instead, ecological connectivity among open habitats has greatly decreased as cereal fields, vineyards, meadows and pasturelands have almost disappeared. Butterfly assemblages under changing land-uses highlights the importance of agro-forest mosaics for biodiversity conservation in the last decades. Hence the suitability of forest transitions should be critically examined in relation to context and policy objectives. Our work emphasizes that conservation of landscapes with a long history of human use needs to take into account the role of humans in shaping ecological features and biodiversity.

\section{Keywords}

Forest-transition; agroforestry system; landscape functionality; butterflies; biological conservation; Mediterranean. 


\section{Introduction}

Widespread agricultural land abandonment can result in forest transition (Kauppi et al. 2006), which in turn is one aspect of the double-sided process of current land-use change: land intensification and land dereliction. Many developed countries ranging from Europe to the United States experienced forest transition during the $19^{\text {th }}$ and $20^{\text {th }}$ centuries (Mather et al. 1999; Rudel et al. 2005). The prevailing landscape trend in the developed world over the last five decades has been the growth of urban sprawl and industrial sites, related to transport and energy networks, surrounded sometimes by rings of intensive and mechanized agriculture; while the rest of the land has increasingly tended to be abandoned and reforested spontaneously, particularly in the Mediterranean region (Vos and Meeks 1999; Lambin and Geist 2006; Gerard et al. 2010). This has boosted scholar interest to examine the prospects and policy options for a global forest transition that would eventually halt worldwide deforestation (Meyfroidt and Lambin 2011).

The forest transition hypothesis reflects processes embedded in the history of mid-latitude forest use, one that may not play out similarly in other biomes of the world where the bulk of global deforestation is occurring nowadays (Turner and Robbins 2008). Furthermore, lower pressures on forests in transition have often been reached, at least in part, by importing wood products from countries with declining forests, thus the potential of global forests return may be lower than suggested by national trajectories (Meyfroidt et al. 2010; Kastner et al. 2011). Some authors suggest that forest transitions should be enhanced by policymakers given their potential for slowing down soil erosion, improving water quality, and slowing climate change through carbon sequestration (Rudel et al. 2005). However, in fire-prone biomes such as the Mediterranean, the uncontrolled expansion of unmanaged forests leads to increased wildfire hazard (Pausas et al. 2008) causing social and ecological negative impacts.

The effects of forest transition(s) in landscape features and biodiversity also merit reflection. As many forest transitions occur in urbanizing areas, and as long as a significant portion of new metropolitan areas follow the pattern of sprawled developments, new forests may have high levels of fragmentation and invasion of exotic species (González-Moreno et al. 2013). In rural 
areas, land abandonment and forest expansion often lead to lower landscape heterogeneity with negative repercussions on biodiversity, especially for those species that benefit from open habitats and edge environments (Giampietro 1997; Marull et al. 2010 and 2014). New approaches to nature conservation recognize the role of these seemingly ordinary landscape mosaics as ecological connectors, and challenge at the same time the belief that protecting natural sites means shielding them from human activity (Farina 2000; Agnoletti 2006). Therefore, the ecological functioning of many cultural landscapes in the Mediterranean depends mainly on whether the agro-forest mosaics they contain are maintained or lost.

Since these agro-forest mosaics come from human intervention in ecosystems, while at the same time natural processes continue to function within them, they become a kind of 'nature transformed' by economic, social and cultural processes (Naveh 1995 and 2001). Thus, to understand and manage agroforestry systems correctly (carbon sequestration, air and water quality, etc.), we need an interdisciplinary approach to cultural landscapes capable of bridging natural and social sciences (Tress et al. 2001; Jose 2009). Moreover, recovering the historical dynamics concealed behind our current land-use patterns becomes a necessity for the emerging integrated approach to biological conservation, which seeks a more complex and multidimensional management of cultural landscapes (Farina 2000; Antrop 2006; Matthews and Selman 2006; Rössler 2006). However, our knowledge of the socio-ecological history of Mediterranean landscapes is currently limited by available sources.

The ecological patterns and processes generated by these agro-forest mosaics gave rise to a set of microhabitats for a great variety of plants and animals (Alverson et al. 1998). While the historical sources still have some value regarding the information they contain, to go beyond their limitations other spatial scales and types of databases are needed, such as bio-indicators that can testify in the last decades the impact of these vanishing traditional agro-forest mosaics (landscape units but also smaller fragmented areas) in a reforesting landscape. Butterflies are particularly sensitive to such habitat changes, a fact that has been shown repeatedly in different studies and areas (Erhardt 1985; Fuller and Warren 1993; Stefanescu et al. 2009; Brückmann et al. 2010). Indeed, the importance of cultural landscapes and traditional farming is now 
commonly accepted as a key element to stop the serious decline of butterfly richness in Europe (van Swaay et al. 2012), as an expression of biodiversity loss. For the Mediterranean region, in particular, Verdasca et al. (2012) have recently shown how agricultural abandonment and forest transition affect negatively butterfly diversity in cork oak forests.

The paper shows that current debate on the restorative character of forest transitions for ecosystems and biodiversity lack a crucial discussion regarding the loss of cultural landscape mosaics. We analyze how forest recovery linked to rural outmigration has led to lower landscape quality in a mountain area representative of the Mediterranean environmental change. The location-specific case study approach is justified since it allows to present in-depth insights that might be lost in a broader geographic approach. We analyze a unique set of detailed cartographic data on land-uses spanning over a period of 160 years from the vantage point of landscape ecology (Turner 2005) to show how forest expansion has decreased the capacity of landscape to host ecological processes and biodiversity, as open habitats -created and enhanced by peasant management- were gradually buried by forest. Finally, the paper critically reexamines at landscape and locale scales the current debate on biodiversity recovery in relation to the well-known global forest transition framework.

\section{Methods}

\subsection{Study region and site}

The Metropolitan Region of Barcelona is located in the north-eastern coast of the Iberian Peninsula, hence in the north rim of the Mediterranean Basin (Figure 1). Contrasting topography (elevation ranges from 0 to $1,700 \mathrm{~m}$ a.s.1.) and climate (gradients NE-SW from moist to dry and SE-NW from less to more continental) bring about a rich land variability. Together with the historical land stewardship -characterized by the management of integrated agrosilvopastoral systems- this variability resulted in high landscape heterogeneity. Until the 1950s, complex and diverse land-use mosaics made with crops, pastures and woods spanned across the lowland areas up to the mountain ranges, and were structured by a network of small cities, villages and 
farmhouses. Later on, the region's intense development led to a massive spread of urban and industrial areas, which increased at the expense of croplands in the lowlands. Mountain ranges instead witnessed a progressive abandonment of rural activities that fostered the expansion of woodlands in marginal agricultural areas. With about 4.9 million people, the metropolitan Barcelona is now one of the most densely populated regions in Europe. Yet it still hosts a number of important natural areas featuring considerable ecological diversity, and it accounts for more than 40 habitats of European significance, including many species of fauna and flora that are either endangered or threatened with extinction (Marull et al. 2007).

Research was conducted in the Catalan Coastal Range, which stretches for over $150 \mathrm{~km}$ along the metropolitan coast. Some of these mountains acted as inner agricultural frontiers during the $18^{\text {th }}$ and $19^{\text {th }}$ centuries, when population growth and an increased demand for cash crops fostered the clearance of forests to establish new cropland. For one particular site (Olzinelles, $22.87 \mathrm{~km} 2$, Figure 1) there is an unusually rich set of data on historical land-uses, which allowed us to reconstruct the particular pathway of forest transition experienced during the last 160 years. As a consequence of land-use changes several species mainly reliant on the existence of human-made open habitats have been reported to be receding in the last decades, both in Olzinelles and Montnegre mountains, the larger range where it belongs (Table 1).

\subsection{Cartographic sources}

Three digital land-use maps of the study area were drawn from the cadastral cartography, available for the years 2013 (Directorate General for Cadastre, Spanish Ministry of Finances and Public Administrations), 1954-56 (Town Council of Sant Celoni and Cadastral Regional Authority), and 1856 (Archives of Instituto Geográfico Nacional, ref. D-12-5). The 2013's cartographic base and associated data on land-uses were downloaded from the Directorate General for Cadastre Electronic Site (www.sedecatastro.gob.es/ovcinicio.aspx) in standard GIS files. Plot polygons were then labelled with their corresponding land-use as reported by the associated data. Photointerpretation of orthophotos taken in 2012 (provided by the Cartographic Institute of Catalonia at a scale of 1:5000, available at www.icc.cat) was used to correct 
mistakes and to refine the cadastral information where necessary. The 1954-56 cadastral maps were scanned and georeferenced in the GIS. Hence plot layout was drawn using as a basis the plot layout of 2013, which was edited according to the information provided by the scanned maps. Backward reconstruction was chosen because the cadastral plot layout of 2013 is basically the same as the one of 1954-56 -with small deviations owing to a different format and nature of sources- except in the areas parcelled for development in the 1960s (Figure 2), where the original layout was redrawn. Plot polygons were then labelled with their corresponding (main) land-use as reported by the associated tables, obtained at the Town Council of Sant Celoni. Information gaps and doubts were solved through photointerpretation of the aerial photographs of 1956 (provided by the Cartographic Institute of Catalonia at a scale of 1:30,000, available at www.icc.cat). The 1856 map (scale 1:5000, copy of the original map drawn in 1853) was photographed and sent to the authors by the staff of the Instituto Geográfico Nacional in Madrid. The photograph was scanned at high resolution and georeferenced in the GIS. Hence plot layout was drawn using as a basis the plot layout of 1954-56, which was edited and adapted to the information provided by the scanned map. Polygons were then labelled with their corresponding (main) land-use as reported by the statistical data of Olzinelles municipality from 1853 (Archives of the Crown of Aragon, ref. TER-963). Both the $19^{\text {th }}$ century map and statistics are part of the documentation produced by the Spanish fiscal reform of 1845 and were done by the same surveyor who allegedly used a common codification of plots. Yet some mismatches between the plot codes in the map and the plot codes in the statistics occurred. Such mismatches were addressed by correlating both codifications through known plots, i.e. plots that could be undoubtedly identified in both sources because they contained the name of the house. When the map had more than one plot with the same code, land-uses reported by the statistics were assigned to the different plots according to plot size and geographical criteria. Land-use categories from different sources were then grouped and homogenized in a common classification of land-covers to allow for inter-comparison and analysis of change (Figure 2).

The cadastral sources mentioned above were used to create three databases with information on land-use and landownership structure. Each database (years 1853, 1954 and 2013) included all 
the plots reported by the corresponding source. Information -introduced at plot level, each plot being a row- included all land-uses reported for that plot and their relative area within the plot. It also included a column with the main land-use of the plot (the one with the largest relative area), the total area of the plot and the name(s) of the landowner(s). Likewise as with the maps, land-use categories from different sources were homogenized in a common classification, even with higher detail in forest types so as to grasp the change of woodland and forest use throughout time.

\subsection{Assessing landscape ecological patterns and processes}

Our hypothesis is that land cover diversity of traditional agro-forest mosaics (different landscape units and smaller fragmented spaces) offers more habitats to diverse species, creating a greater amount of ecotones which in turn furnish more opportunities to edge species (Benton et al. 2003; Marull et al. 2010), as well as a more permeable matrix allowing dispersal among local populations (Shreeve et al. 2004; Lizée et al. 2012). Therefore, thanks to the so-called 'edge effect' and a more permeable matrix, agroforestry systems could host a greater biodiversity than the more uniform land covers we have currently (Harper et al. 2005; Gabriel et al. 2006).

In order to check this hypothesis with the available historical land-use maps, we analysed the corresponding shifts in landscape patterns of the study area by using the following metrics of land cover change, diversity and fragmentation (Jaeger 2000; Marull and Mallarach 2005; Marull et al. 2007; Moser et al. 2007): Land Cover Change (measures the cell average of the landscape unit change -urban areas, forest, pasture, and cropland-of each pixel), ShannonWiener Index (H'; as used to measure land cover diversity) (Eq. (1)) and Effective Mesh Size (MESH; sum of the areas of the squared polygons divided by the size of the study area) (Eq. (2)).

$H^{\prime}=-\sum\left(P_{i} \ln P_{i}\right)$

where $P_{i}$ is the proportion of land matrix occupied by each type of cover. 
$\operatorname{MESH}=\sum\left(A_{i}^{2}\right) 1000 / \Sigma\left(A_{i}\right)$

where $A_{i}$ is the area of each polygon.

To assess landscape processes we have calculated the land matrix ecological connectivity (sensu Lindenmayer and Fisher 2007) applying the Ecological Connectivity Index (ECI; using a simplification of the original methodology proposed by Marull and Mallarach 2005).

The diagnosis of ecological connectivity relies on defining a set of Ecological Functional Areas (EFA; landscape units) and a computational model of cost-distance in displacements, which includes the effect of the modelled anthropogenic barriers, considering the type of barrier, the range of distances and the kind of land use involved. This model has been applied by GIS to the available historical land-use maps. As a first step, to calculate $E C I$ all different land cover categories used in each map were reclassified in landscape units (forest, pasture, and cropland). Then, in order to establish the EFA, the landscape units (forest, pasture, and cropland) were grouped in terms of their ecological affinity, and subsequently performing a topological analysis based on the criteria of minimum requirements and compactness indicated in the literature (Andrén 1994; Fahrig and Merriam 1994; Bender et al. 1998).

The next step of the model is to consider the barrier effect. An impact analysis of the space surrounding each anthropogenic barrier is performed by means of a weighted classification of landscape units that act as barriers to ecological connectivity. The algorithm used is based on a computational model of cost-distance in displacements, which includes a weight of each type of barrier and a potential matrix of affected land use. The model applies the function Cost Distance of the ArcGis software and uses two databases: a 'source' surface for each type of barrier $\left(X_{B s} ; s\right.$ $=1 \ldots 5)$ and an 'impedance' surface from the potential matrix of affected areas $\left(X_{A}\right)$. From this process we obtain a cost distance adapted $\left(d^{\prime}{ }_{s}=b_{s}-d_{s}\right.$; where $b_{s}-d_{s}>0$; being $d_{s}$ the cost distance). Then we assume that the effect of an anthropogenic barrier in point $Y_{\mathrm{S}}$ of the surrounding space is logarithmic, and decreases as a function of the distance (Kaule 1997) (Eq. (3)), so that:

$Y_{S}=b_{s}-k s_{1} \ln \left[k s_{2}\left(b_{s}-d_{s}^{\prime}\right)+1\right]$ 
where $b_{s}$ is the weight of each barrier (based on residential density or intensity of traffic, for example), $\mathrm{ks}_{1}$ and $\mathrm{ks}_{2}$ are constants (estimated from the distribution obtained using empirical data) and $d^{\prime}{ }_{s}$ is the cost distance adapted for each barrier-see Marull and Mallarach (2005) for methodological details.

The barrier effect $Y$ (Eq. (4)) is defined as the sum of effects of all types and the cartographic expression obtained as a result is a surface:

$Y=\sum Y_{s}$

So we finally come to the connectivity index. The algorithm used to determine the ecological connectivity between landscape units (forest, pasture, and cropland) applies a computational model of cost distance, which considers the different classes of EFAs to connect and an impedance surface of land that includes a matrix of potential affinity together with the effect of anthropogenic barriers. Again the model applies the function CostDistance of the ArcGis software using two databases: a 'source' surface for each type of functional ecological area $\left(X_{C^{\prime}} ; r=1 \ldots 3\right)$ and an 'impedance' surface resulting from applying the effect of barriers to the potential affinity matrix $\left(X_{I}=X_{C^{\prime} r}+X_{Y}\right)$. This way, you get a cost distance adapted to each type of functional ecological area $\left(d^{\prime}{ }_{r}<20,000\right.$ to avoid irrelevant information or concealment of results). Finally, we calculate the value of the sums of cost distances adapted. From the computational model of ecological connectivity described above, we formally define a basic ecological connectivity index $\left(E C I_{b}\right)$ in a normalized range that always moves from zero to ten (Eq. (5)). This $E C I_{b}$ emphasizes the role played separatelyby each landscape unit (forest, pasture or cropland) on the land matrix ecological connectivity:

$E C I_{b}=10-9\left[\ln \left(1+x_{i}\right) / \ln \left(1+x_{t}\right)^{3}\right]$

where $x_{i}$ is the value of the sum of the cost distance by pixel and $x_{t}$ the maximum theoretical cost distance.

Then, $E C I_{a}$ is the absolute Ecological Connectivity Index (Eq. (6)):

$E C I_{a}=\sum E C I_{b} / m$ 
where $m$ is the absolute number of functional ecological areas considered. As we will see, this index helps to emphasize the role played by all sorts of landscape units (forest, pasture, and cropland) to keep up ecological connectivity (Pino and Marull 2012; Parcerisas et al. 2012).

\subsection{In search for bio-indicators: Mediterranean butterflies in vanishing agro-forest mosaics}

To test the effects of land abandonment, forest transition and the progressive loss of agricultural mosaics on biodiversity, we have used recent data on the butterfly community in Olzinelles, at local scale. Butterflies were monitored in the study area from 1994 to 2012 at two different sites, 'Can Riera de Vilardell' and 'Can Valls d'Olzinelles'. Both sites are part of the network known as the Catalan Butterfly Monitoring Scheme or CBMS (www.catalanbms.org). This monitoring program is based on standardized weekly surveys of adult butterflies conducted along fixed routes during the flight season (30 weeks, from March 1 to September 26). During each visit to a site, an observer walks a fixed transect route of about $2 \mathrm{~km}$ in length, recording all butterflies seen within a 5-m corridor. Transects are divided into a number of different sections, each corresponding to a particular habitat type -see van Swaay et al. (2008) for a summary of the standard methodology. The main objective of the CBMS is to measure butterfly population fluctuations at the country level (Catalonia and Andorra) and to relate them with different environmental factors.

'Can Riera de Vilardell' and 'Can Valls d'Olzinelles' transects were active between 1994-2005 and 2006-2012, respectively, and counts were always made by the same two recorders (MM and, secondarily, CS). Both transects sampled a combination of evergreen oak and cork forests, and grasslands (hay and pasture meadows). However, in 'Can Riera de Vilardell', grasslands were planted with maritime pines (Pinus pinaster) in 1993, and by the end of the 12-yr recording period had been completely replaced by a very dense stand of trees of more than $10 \mathrm{~m}$ high. These shifts exemplify one of the common changes occurred in the study area in the last decades contributing to forest transition. A detailed account of the transect route and the changes in the butterfly community can be found in Miralles and Stefanescu (2004; see also Tables A1 and A2). On the other hand, in the 'Can Valls d'Olzinelles' transect, some parts of 
the woodland were clear cut at the start (2006) and the end of the recording period (2011), being progressively replaced by open areas. These management practices were executed by the Montnegre-Corredor Natural Park, as part of a project called 'Improvement in the hydrological and other natural resources in the Olzinelles valley', aimed at restoring open habitats in the valley.

According to our hypothesis, we expected a reduction of species richness in the 'Can Riera de Vilardell' transect following the disappearance of the agro-forest mosaics, and the converse trend in the 'Can Valls d'Olzinelles' transect. At each site, a test of proportions (one tail) of the species recorded out of the pool of local species was used to confirm if there had been a significant change in species richness between the start and end of the respective recording periods (a decrease in 'Can Riera de Vilardell', an increasein 'Can Valls d'Olzinelles'). The test formula was (Eq. (7)):

$$
Z^{*}=\frac{\left(p_{\text {initial }}-p_{\text {final }}\right)}{\sqrt{p^{r}\left(1-p^{r}\right)\left(\frac{1}{n_{\text {initial }}}+\frac{1}{n_{\text {final }}}\right)}}
$$

where $p^{*}=\frac{n_{\text {initial }} \cdot p_{\text {initial }}+n_{\text {final }} \cdot p_{\text {final }}}{n_{\text {initial }}+n_{\text {final }}}$, and the criteria to reject the null hypothesis:

$P\left(Z^{*}>Z\right)=\alpha$, where $Z \sim N(0,1)$

To assess that changes in the butterfly communities at local scale were in the expected directions due to habitat changes, we further investigated the trend over time in the number of individuals of species preferring grasslands versus those preferring woodland. Habitat preferences had previously been quantified by using the whole CBMS dataset (period 19942011, 118 sites). Each section in a given transect was classified by a professional botanist as open (grassland) or closed (woodland) habitat, according to information on the cover of plant communities (following the CORINE classification) occurring in a $5 \mathrm{~m}$ buffer along the recording route (Suggitt et al. 2012). We selected sections with at least $75 \%$ of recovery of closed or open habitats, respectively, to avoid mixed habitats. Afterwards, for each butterfly species, we carried out a generalized linear model with a Poisson error distribution and a log link function, specified with the abundance of the species as the response variable and the $\%$ of 
forest habitat as the independent factor for each species. The estimates values of the GLM have been used as a measure of the affinity of a given species for an open or a close habitat. More positive values indicate a stronger preference for closed areas, and negative values a stronger affinity for open areas. Finally, a linear regression was used to calculate the trend over time in the percentage of individuals belonging to grassland species in both transects. For this calculation, species with negative values were considered as preferring open habitats and species with positive values as preferring closed habitats.

\section{Results and discussion}

\subsection{Forest transition pathway}

After the demographic growth of the mid- $19^{\text {th }}$ century and as the Phylloxera plague hit local vineyards during the last decades of the century, some of the small vine-growing peasants abandoned their vineyards. They most likely moved as workforce to Sant Celoni village, where an incipient local industry based on textiles, cork, wood and milk was developing since the arrival of the railway. As opportunities for better-off paid non-farm jobs increased in nearby coastal and industrial towns many tenant peasants, small estate owners and forest day labourers left Olzinelles during the first decades of the $20^{\text {th }}$ century (Otero et al. 2013). Cereal fields and vineyards were gradually abandoned, making way for oak forests to recover spontaneously and for plane trees and pines to be planted by landowners (Table 2).

Forest cover increased substantially during the last 160 years (Figure 2). Instead, rain-fed arable land, vineyards and pastures decreased markedly. Irrigated arable land showed an oscillating trend. Urban and unproductive areas and the road network expanded during the last decades. In the mid- $19^{\text {th }}$ century, the largest estates (> 100 ha) were mainly devoted to forests and pastures, while the smallest properties were mostly agricultural lands, vineyards being the major land-use of small peasants (Table 2). One century later, the largest estates were definitively forest ones. In the smallest plots agricultural uses still represented a significant proportion of the area, but forest uses (especially pines and Cork oaks) gained importance. In 2012 the relative importance 
of small landowners $(<1 \mathrm{ha})$ increased due to parcelling for housing, their properties being mostly devoted to urban uses.

In 1856 forests and pastures were mostly located in the northern and southern areas (Figure 2). They intermingled with patches of rain-fed arable land and vineyards set up around farmhouses, which were scattered across the hills and the valley bottoms. A concentration of vineyards -and to a lesser extent, of rain-fed arable land-was located in the north-western area, closer to the Sant Celoni village and the Tordera River. By 1954-56 pasture was irrelevant and the areas of vineyard concentration had contracted with respect to 1856 (Table 2; Figure 2). Irrigated arable land was larger instead, with some plots scattered along the Tordera River and in farmhouses of the valley bottoms. Even if landscape was clearly dominated by forests, these were still intermingled with patches of rain-fed arable land and vineyards showing a spatial arrangement resembling the one in 1856. In 2013 rain-fed arable land witnessed a strong contraction (Table 2) and only some remnant patches persisted in the valley bottoms. Vineyards almost disappeared since only one plot existed in the southernmost part of the study area. Urban areas consisting of single house plots and the highway are now distinctive landscape elements (Figure 2).

Depopulation and land-use changes in Olzinelles constitute a paradigmatic example of what has occurred in many Catalan mountain areas. As a result of land abandonment, spontaneous regeneration of forest and promoted tree plantation, woodland greatly increased in Catalonia in the last century. Thus the economic modernization pathway seems to explain the forest transition our study area and the whole region experienced (Rudel et al. 2005).

\subsection{Effects of forest recovery on landscape patterns and processes}

At landscape scale, forest recovery occurred at the expense of vineyards, pastures and rain-fed arable land (Figure 2). As a consequence, there has been a decrease in land-use equi-diversity (as measured by $H^{\prime}$ ) and a decrease in the global ecological connectivity (measured as $E C I_{a}$ ), show in the disappearance of ecological functional areas $(E F A)$. 
Effective Mesh Size (MESH) is the inverse of the extent of fragmentation, and Shannon-Wiener Index $\left(H^{\prime}\right)$ measures the land cover equi-diversity. The results show a negative correlation between both variables (Figure 3). There is a clear trend to less landscape fragmentation from 1856 to 1954-56 due to forest transition (that implies a loss of agriculture and pasture land cover categories), and also an upward trend from 1954-56 to 2013, with most of the landscape reforested. $H^{\prime}$ shows a constant decrease from 1856 to 2013 due to the loss of almost all the traditional agro-forest mosaics in the study area.

We have also adjusted the methodology, in terms of the criteria and the constants that must be incorporated in a quantitative landscape ecology model to analyze the historical land cover change (1856-2013) in the study area. For each time point we have calculated $E C I_{b}\left(C^{\prime}{ }_{1}\right.$ 'forest'; $C_{2}{ }_{2}$ 'agriculture'; and $C_{3}{ }_{3}$ 'pasture' (Figure A1) and $E C I_{a}$ (all categories included; Figure 4). The results show the importance of agriculture and pasture land cover categories to maintain the global ecological connectivity and the key role played by traditional agro-forest mosaics (Figure 2) in keeping ecological functionality.

The non-forested habitats are clearly the result of peasant management of local resources both to make a living and to produce cash crops. Hence the 'forest approach' obscures the importance of these other non-forested or sparsely tree-covered habitats which can be considered, in the Mediterranean area, to be human induced habitats through a medium perturbation regime (Margalef, 2006). Of course we are not saying that forests are not important habitats, but beyond a certain surface occupied by woodland an increase in forest area did not increase $E C I_{b l}$ significantly; on the other hand, $E C I_{b 2}$ and $E C I_{b 3}$ decreased dramatically as ecological functional areas disappeared (crops, pastures). This led to the disappearance and recessive trends of a broad range of species from different taxonomic groups (Table 1). Butterfly assemblages highlight this reasoning.

\subsection{Effects of forest recovery on biodiversity}

At local scale, the bioindicator taxon used confirmed the negative impact of the vanishing agroforest mosaics on biodiversity in the last decades. Butterfly species richness decreased markedly 
in 'Can Riera de Vilardell' transect following the disappearance of grasslands (Figure 5). The proportion of recorded species out of the local pool was lower in 1994 than in 2005 (Z-test = 2.22; $P=0.0132$ ), showing a loss of biodiversity during the study period. On the other hand, there was no clear trend in the 'Can Valls d'Olzinelles' transect (Figure 5), as indicated by a non-significant value in the proportion of recorded species at the beginning and at the end of the study (Z-test $=0.39 ; P=0.349)$.

The loss of species richness in 'Can Riera de Vilardell' was the obvious consequence of a strong population decline in grassland species as the habitats were replaced by pine plantations (Figure 6), leading to the local extinction of several species. It is worthwhile noting that although butterflies were monitored for only 12 years (1994-2005) at the very end of our study period (1853-2013), the results are truly representative of a process of biodiversity loss that has been occurring continuously in Olzinelles for more than one century as open areas disappeared and landscape connectivity decreased.

In 'Can Valls d'Olzinelles' we observed an opposite trend, with a significant increase in the proportion of butterflies preferring open habitats, as some forest patches were cut by the Natural Park for conservation purposes and open areas appeared (Figure 6). In this case, however, the change in the dominant species was not accompanied by an increase in species richness. Three factors account for this: first, the very poor quality of the new created open habitats, which had been mainly colonized by invasive (alien) plant species that prevent the growth of diversified grasslands (González-Moreno et al. 2013); second, the low connectivity between the few remaining grasslands (Figure A1) that hamper greatly the colonization process carried out by typical grassland butterfly species, which nowadays persist in the region as isolated and small populations (Thomas and Hanski 2004); and third, the short time span since the forest clearance took place. In any case, the failure in the attempt to increase butterfly species richness in the last decades highlights the difficulty in recovering the lost ecological processes that should host biodiversity in these former complex Mediterranean cultural landscapes.

It is likely that in the traditional integrated land-use patterns, grazing areas overlapped among grasslands, scrublands and sparse oak woods in a manner almost incomprehensible for people 
lacking the oral knowledge locally conveyed by villagers who managed these agroforestry systems (Grove and Rackham 2001; Otero et al. 2013). With the peasant activity and the passing of time these woodlands probably became more spaced out from each other and were able to grow taller. Sunlight penetrated inside what had been a canopy, allowing the grassy layer of the land to grow herbs which could be eaten by livestock. These cultural woodland-meadows not only increased the spatial heterogeneity of forestlands inside a mosaic with pastures and cropland, but created greater differentials in the height and age of the trees (Campos et al. 2013). The edge effect generated by these landscape mosaics gave rise to a set of microhabitats for a great variety of plants and animals (Alverson et al. 1998). When traditional extensive livestock rearing came to a sudden end in the 1960s, this multiple and integrated agro-forestrypastoral use of land suddenly collapsed. However, this story remains hidden below the onedimension categorizations of land-uses found in the historical available sources.

\section{Conclusions}

This article critically re-examines the forest transition hypothesis, which suggests that forest recovery led by economic development has positive effects on biodiversity. At the very heart of this question lies a fundamental debate on the relationship between human settlement and biodiversity conservation. The dominant view states that the former is incompatible with the latter as settlement and productive activities disrupt many ecosystem processes. An alternative view instead suggests that they are not necessarily incompatible; humans may even enhance biodiversity through a historical process of land stewardship within integrated socio-ecological systems. The first view has been recently reinvigorated by a series of works on forest transitions (Grau and Aide, 2008). Given the high human social costs of the conservation strategies that stem from this approach (West et al., 2006) it seems worth revisiting it in different biomes of the world and in the light of methods and approaches from different disciplines. Hence, we should not confuse the debate over 'wilderness' in Europe and the debate over 'biodiversity' conservation and the Mediterranean agroforestry system. 
Recently Robson and Berkes (2011) questioned the assumption that forest gain necessarily equates with biodiversity conservation. They pointed out that agricultural land abandonment linked to rural outmigration may result in a gradual loss of agro-forest mosaics, leading to localized declines in biodiversity, despite (or because of) extensive forest resurgence. Hence, the suitability of forest transitions should be critically examined in relation to spatial scale and policy objectives. Mediterranean agro-forest mosaics carry a long socio-ecological history behind (Blondel et al., 2010), and hence assessing and understanding the environmental functionality of the agroforestry system requires an analysis of land-use patterns and ecological processes seen from a dynamic historical standpoint. Our case study exemplifies a widespread phenomenon that is taking place under current global change pressures in many parts of southern Europe. Here, we raise the need to consider these agro-forested mosaics as a priority in biological conservation and urban planning, given their capacity to host biodiversity and keep up environmental services in the future.

Consequently the key question is not so much to stress that forest recovery driven by rural outmigration led to dramatic changes in landscape patterns, ecological processes and biodiversity, and thus to call for maintaining cultural landscapes with mosaic of habitats, but rather the issue is what kind of understanding of historical-geographical change is appropriate for a conservation science analysis. Forest dynamics are not the same in different biomes. The debate over these changes, especially in North America, tends to underestimate the cultural and historical dimensions of European landscapes, and to contribute to the confusion between 'wilderness' and 'biodiversity' concepts. Most of the biodiversity in European cultural landscapes is related to long land-use, and human-made farm lands. Arguing for the conservation or restoration of such landscapes is normative, other researches may stress that at the European level we can accept or even promote forest transition, but it will depends of the agroforestry system functioning and the scale of analysis (McNeely 2004; Jose 2009). 


\section{Acknowledgements}

This work has been supported by the research project HAR2012-38920-C02-02 funded by the Spanish Ministry of Economy and Competitiveness, and the international Partnership Grant SSHRC- 895-2011-1020 'Sustainable farm systems: long-term socio-ecological metabolism in western agriculture' funded by the Social Sciences and Humanities Research Council of Canada. The council of Sant Celoni gave full support for the butterfly monitoring.

\section{References}

Agnoletti M. (ed.) (2006) The Conservation of Cultural Landscapes.Wallingford: CABI Pub. Alverson WS, Waller DM, Solheim SK (1988) Forest to Deer: Edge Effects in Northern Wisconsin. Conservation Biology 2: 348-58.

Andrén H (1994) Effects of habitat fragmentation on birds and mammals in landscapes with different proportions of suitable habitat: a review. Oikos 71: 355-366.

Antrop M (2006) Sustainable landscapes: contradiction, fiction or utopia? Landscape and Urban Planning 75: 187-197.

Bender DJ, Contreras TA, Fahrig L (1998) Habitat loss and population decline: a meta-analysis of the patch size effect. Ecology 79: 517-533.

Benton TG, Vickery JA, Wilson JD (2003) Farmland biodiversity: is habitat heterogeneity the key? Trends in Ecology and Evolution 18: 182-8.

Blondel J, Aronson J, Bodiou J-Y, Boeuf G (2010) The Mediterranean region. Biological diversity though time and space. Oxford University Press, $400 \mathrm{pp}$.

Brückmann S, Krauss J, Steffan-Dewenter I (2010) Butterfly and plant specialists suffer from reduced connectivity in fragmented landscapes. Journal of Applied Ecology 47: 799-809.

Campos P, Huntsinger L, Oviedo JL, Starrs PF, Diaz M, Standiford R, Montero G (2013). Mediterranean Oak Woodland Working Landscapes. Springer, 508 pp.

Erhardt A (1985) Diurnal Lepidoptera: sensitive indicators of cultivated and abandoned grassland. Journal of applied Ecology 22: 849-861. 
Farina A (2000) The Cultural Landscape as a Model for the Integration of Ecology and Economics. BioScience 50: 313-20.

Fahrig L, Merriam G (1994) Conservation of fragmented populations. Conservation Biology $8 ; 50-59$.

Fuller RJ, Warren MS (1993) Coppiced woodlands: their management for wildlife. Joint Nature Conservation Committee, UK.

Gabriel D, Roschewitz I, Tscharntke T, Thies C (2006) Beta diversity at different spatial scales: plant communities in organic and conventional agriculture. Ecological Applications 16: 201121.

Gerard F, Petit S, Smith G, Thomson A, Brown N, Manchester S, Wadsworth R, Bugar G, Halada L, Bezak P, Boltiziar M, De Badts E (2010) Land cover change in Europe between 1950 and 2000 determined employing aerial photography. Progress in Physical Geography 34: 183205.

Giampietro M (1997) Socioeconomic constraints to farming with biodiversity. Agriculture, Ecosystems and Environment 62: 145-167.

González-Moreno P, Pino J, Carreras D, Basnou C, Fernández-Rebollar I, Vilà M (2013) Quantifying the landscape influence on plant invasions in Mediterranean coastal habitats. Landscape Ecology 28: 891-903.

Grau HR, Aide TM (2008) Globalization and land use transitions in Latin America. Ecology and Society 13: 16-27.

Grove AT, Rackham O (2001) The Nature of Mediterranean Europe: an ecological history. New Haven, Yale University Press.

Harper KA, MacDonald SE, Burton PhJ, Chen J, Brosofsfe KD, Saunders SC, Euskirchen ES, Robert D, Jaiteh MS, Esseen P-A (2005) Edge Influence on Forest Structure and Composition in Fragmented Landscapes. Conservation Biology 19: 768-82. Jaeger JAG (2000) Landscape division, splitting index, and effective mesh size: new measures of landscape fragmentation. Landscape Ecology 15: 115-130. 
Jose S (2009) Agroforestry for ecosystem services and environmental benefits: an overview. Agroforestry Systems 76: 1-10

Kastner T, Erb K-H, Nonhebel S (2011) International wood trade and forest change: A global analysis. Global Environmental Change 21 (3): 947-956.

Kaule G (1997) Principles for mitigation of habitat fragmentation. In Canters (Ed.), Proceedings of the International Conference on Habitat Fragmentation, Infrastructures and the Roles of Ecological Engineering.Maastricht and The Hague, TheNetherlands, September 1995, 17-21.

Kauppi PE, Ausubel JH, Fang J, Mather AS, Sedjo RA, Waggoner PE (2006) Returning forests analyzed with the forest identity. Proceedings of the National Academy of Sciences of the United States of America 103 (46): 17574-17579.

Klooster D (2003) Forest transitions in Mexico: institutions and forests in a global countryside. The Professional Geographer 55 (2): 227-237.

Kull CA, Ibrahim CK, Meredith TC (2007) Tropical forest transitions and globalization: neoliberalism, migration, tourism, and international conservation agendas.Society and Natural Resources 20: 723-37.

Lambin EF, Geist H (eds.) (2006) Land-use and land-cover change: local processes and global impacts. Berlin, Springer.

Lindenmayer DB, Fischer J (2007) Tackling the habitat fragmentation panchreston. TREE 22: $127-132$

Lizée M-H, Manel S, Mauffrey J-F, Tatoni T, Deschamps-Cottin M (2012) Matrix configuration and patch isolation influences override the species-area relationship for urban butterfly communities. Landscape Ecology 27: 159-169.

McNeely JA (2004) Nature vs nurture: managing relationships between forests, agroforestry and wild biodiversity. Agroforestry Systems 61:155-165

Margalef R (2006) Ecological Theory and Prediction in the Study of the Interaction between Man and the Rest of Biosphere, in Siolo $\mathrm{H}$ (ed.), Ökologie und Lebensschutz in IntrenationalerSicht, Freiburg: Rombach, 1973; reprinted in Catalan, Spanish and English in Medi Ambient. Tecnologia i Cultura 38: 114-125. 
Marull J, Mallarach JM (2005) A new GIS methodology for assessing and predicting landscape and ecological connectivity: Applications to the Metropolitan Area of Barcelona (Catalonia, Spain). Landscape and Urban Planning 71: 243-262.

Marull J, Pino J, Mallarach JM, Cordobilla MJ (2007) A land suitability index for strategic environmental assessment in metropolitan areas. Landscape and Urban Planning 81: 200-212. Marull J, Pino J, Tello E, Cordobilla MJ (2010) Social metabolism, landscape change and landuse planning in the Barcelona Metropolitan Region. Land Use Policy 27: 497-510.

Marull J, Tello E, Wilcox P, Coll F, Pons M, Warde P, Valldeperas N, Ollés A (2014) Recovering the land-use history behind a Mediterranean edge environment: The importance of cultural landscapes in biological conservation. Applied Geography (in press).

Mather AS (2007) Recent Asian forest transitions in relation to forest-transition theory. InternationalForest Review 9: 491-502.

Mather AS, Fairbairn J, Needle CL (1999) The course and drivers of the forest transition: the case of France. Journal of Rural Studies 15: 65-90.

Matthews R, Selman P (2006) Landscape as a focus for integrating human and environmental processes. Journal of Agricultural Economics 57: 199-121.

Meyfroidt P, Rudel TK, Lambin EF (2010) Forest transitions, trade, and the global displacement of land use. Proceedings of the National Academy of Sciences of the United States of America 107 (49): 20917-20922.

Meyfroidt P, Lambin EF (2011) Global forest transition: prospects for an end to deforestation. Annual Review of Environment and Resource 36: 343-371.

Miralles M, Stefanescu C (2004) Les papallones diürnes del Montnegre. Deu anys de seguiment amb la metodologia del BMS. In: IV Trobada d'estudiosos del Montnegre i el Corredor: 105112. Monografies 38. Diputació de Barcelona, Barcelona.

Moser B, Jaeger JAG. Tappeiner U, Tasser E., Eiselt B (2007) Modification of the effective mesh size for measuring landscape fragmentation to solve the boundary problem. Landscape Ecology 22: 447-59. 
Naveh Z (1995) Interactions of landscapes and cultures. Landscape and Urban Planning 32: 4354.

Naveh Z (2001) Ten major premises for a holistic conception of multifunctional landscapes. Landscape and Urban Planning 57: 269-284.

Otero I, Boada M, Tàbara JD (2013) Social-ecological heritage and the conservation of Mediterranean landscapes under global change. A case study in Olzinelles (Catalonia). Land Use Policy 30: 25-37.

Parcerisas Ll, Marull J, Pino J, Tello E, Coll F, Basnou C (2012) Land use changes, landscape ecology and their socioeconomic driving forces in the Spanish Mediterranean coast (El Maresme County, 1850-2005). Environmental Science and Policy 23: 123-32.

Pausas JG, Llovet J, Rodrigo A, Vallejo R (2008) Are wildfires a disaster in the Mediterranean basin? - A review. International Journal of Wildland Fires 17(6): 713-723.

Pino J, Marull J (2012) Ecological networks: Are they enough for connectivity conservation? A case study in the Barcelona Metropolitan Region (NE Spain). Land Use Policy 29: 684-90.

Robson JP, Berkes F (2011) Exploring some of the myths of land use change:Can rural to urban migration drive declines in biodiversity? Global Environmental Change 21: 844-854.

Rössler M (2006) World heritage cultural landscapes: a UNESCO flagship programme 19922006. Landscape Research 31: 333-53.

Rudel TK, Coomes O, Moran E, Achard F, Angelsen A, Xu J, Lambin E (2005) Forest transitions: towards a global understanding of land use change. Global Environmental Change 15: 23-31.

Shreeve TG, Dennis RLH, Van Dick H (2004) Resources, habitats and metapopulations whither reality? Oikos 106: 404-408.

Stefanescu C, Peñuelas J, Filella I (2009) Rapid changes in butterfly communities following the abandonment of grasslands: a case study. Insect Diversity and Conservation 2: 261-269.

Suggitt AJ, Stefanescu C, Oliver T, Páramo F, Anderson BJ, Hill JK, Roy DB, Thomas CD (2012) Habitat associations of species show consistent but weak responses to climate. Biology Letters 8: 590-593. 
Thomas CD, Hanski I (2004) Metapopulation dynamics in changing environments: butterfly responses to habitat and climate change. In Hanski, I.and Gaggiotti, O.E. (Eds.), Ecology, Genetics, and Evolution of Metapopulation. ElsevierAcademic Press, Amsterdam, pp. 489-514. Tress B, Tress G, Décamps H, d'Hauteserre AM (2001) Bridging human and natural sciences in landscape research. Landscape and Urban Planning 57: 137-41.

Turner BL, Robbins P (2008) Land-change science and political ecology: similarities, differences, and implications for sustainability science. Annual Review of Environment and Resources 33: 295-316.

Turner MG (2005) Landscape ecology: what is the state of the science? Annual Review of Ecology, Evolution, and Systematic 36: 319-344.

Van Swaay CAM., Nowicki P, Settele J, van Strien AJ (2008) Butterfly monitoring in Europe: methods, applications and perspectives. Biodiversity and Conservation 17: 3455-3469.

Van Swaay CAM, van Strien A, Harpke A, Fontaïne B, Stefanescu C, Roy D, Maes D, Kühn E, Ounap E, Regan E, Svitra G, Heliölä J, Settele J, Pettersson L, Titeux N, Cornish N, Leopold P, Julliard R, Verovnik R, Popov S, Collins S, Goloshchapova S, Roth T, Brereton T, Warren M (2012) The European Butterfly Indicator for Grassland species 1990-2011. Report VS2012.019, De Vlinderstichting, Wageningen.

Verdasca MJ, Leitao AS, Santana J, Porto M, Dias S, Beja P (2012) Forest fuel management as a conservation tool for early successional species under agricultural abandonment: the case of Mediterranean butterflies. Biological Conservation 146: 14-23.

Vos W, Meeks H (1999) Trends in European cultural landscape development: perspectives for a sustainable future. Landscape and Urban Planning 46: 3-14.

West P, Igoe J., Brockington D (2006) Parks and peoples: the social impact of protected areas. Annual Review of Anthropology 35: 251-277. 
Table 1 Species reported to be experiencing recessive trends in Olzinelles and Montnegre mountains as a consequence of ceasing management practices of croplands, forests and pastures.

\begin{tabular}{|c|c|c|c|c|}
\hline \multirow{2}{*}{ Group } & \multirow{2}{*}{ Source } & \multirow{2}{*}{ Species } & \multicolumn{2}{|c|}{$\begin{array}{l}\text { Conservation } \\
\text { status/interest }\end{array}$} \\
\hline & & & $\mathrm{UICN}^{(\mathrm{d})}$ & Catalonia $^{(\mathrm{e})}$ \\
\hline Plants & $\begin{array}{l}\text { Gutiérrez } \\
(2001)^{(\mathrm{a})}\end{array}$ & $\begin{array}{l}\text { Geranium lanuginosum } \\
\text { Orobanche artemisiae-campestris picrides } \\
\text { Spergularia purpurea } \\
\text { Erica cinerea } \\
\text { Helianthemum tuberaria } \\
\text { Isoetes durieui } \\
\text { Orobanche teucrii } \\
\text { Stachys alpina }\end{array}$ & $\begin{array}{l}\text { n.a. } \\
\text { n.a. } \\
\text { n.a. } \\
\text { n.a. } \\
\text { n.a. } \\
\text { n.a. } \\
\text { n.a. } \\
\text { n.a. }\end{array}$ & $\begin{array}{l}\mathrm{CR}^{*} \\
\mathrm{VU} \\
\mathrm{VU} \\
\mathrm{LC} \\
\mathrm{LC} \\
\mathrm{LC}^{*} \\
\mathrm{LC} \\
\mathrm{LC}\end{array}$ \\
\hline Butterflies & $\begin{array}{l}\text { Miralles and } \\
\text { Stefanescu } \\
(2004)^{(b)}\end{array}$ & $\begin{array}{l}\text { Maniola jurtina } \\
\text { Polyommatus icarus } \\
\text { Lycaena phlaeas } \\
\text { Leptotes pirithous } \\
\text { Colias crocea }\end{array}$ & $\begin{array}{l}\text { n.a. } \\
\text { n.a. } \\
\text { n.a. } \\
\text { n.a. } \\
\text { n.a. }\end{array}$ & $\begin{array}{l}\text { n.e. } \\
\text { n.e. } \\
\text { n.e. } \\
\text { n.e. } \\
\text { n.e. }\end{array}$ \\
\hline Birds & $\begin{array}{c}\text { Ribas }(1997 \mathrm{a}, \\
1997 \mathrm{~b})^{(\mathrm{c})}\end{array}$ & $\begin{array}{l}\text { Alectori srufa } \\
\text { Coturnix coturnix } \\
\text { Jynx torquilla } \\
\text { Lanius senator } \\
\text { Miliaria calandra } \\
\text { Galerida cristata } \\
\text { Alauda arvensis } \\
\text { Upupa epops } \\
\text { Emberiza cirlus }\end{array}$ & $\begin{array}{l}\text { LC } \\
\text { LC } \\
\text { LC } \\
\text { LC } \\
\text { LC } \\
\text { LC } \\
\text { LC } \\
\text { LC } \\
\text { LC }\end{array}$ & $\begin{array}{l}\text { VU } \\
\text { DD } \\
\text { NT } \\
\text { NT } \\
\text { LC } \\
\text { NT } \\
\text { LC } \\
\text { LC } \\
\text { LC }\end{array}$ \\
\hline
\end{tabular}

Notes:

(a) Gutiérrez performed a review of studies done over the last 60 years. He relied especially on the classical flora of the region by Montserrat ([1950] 1989). Several species were selected according to conservationist criteria. For the selected species, the locations reported by the classical flora were verified in situ to check if they were still present. The major threats were identified for the selected species. The original results (Gutiérrez, 2001, concerning the whole area of Montnegre and Corredor) have been adapted by including only those species reported for Montnegre Mountains. (b) Transect walked in 'Can Riera de Vilardell' (see Figure 1) as part of the Catalan Butterfly Monitoring Scheme, which uses a standardized methodology for monitoring butterflies (Stefanescu, 2000). Between March and September weekly butterfly counts were made along a fixed route within $2.5 \mathrm{~m}$ on each side and $5 \mathrm{~m}$ in front of the recorder (see Pollard and Yates, 1993 for details on the methodology). The transect was $2298 \mathrm{~m}$ long, had a mean altitude of $260 \mathrm{~m}$ a.s.l. and went through different habitats as Holm Oak forest, Cork Oak forest, and former meadows transformed to pine plantations. Data were available for the period 1994-2003. ${ }^{\text {(c) }}$ Bird species distribution was studied by field sampling, the study area being divided following the UTM $1 \mathrm{~km} \mathrm{x} 1 \mathrm{~km}$ squares. Each of these UTM squares were sampled once or twice a year during several years for both breeding (from March to July) and wintering (from November to February) species. In each sampling a transect of about 1-1.5 h of duration was walked whereby bird species were recorded by both visual and hearing contacts, and main habitat preferences were assigned to each of them (Pino et al., 2000). Different standard methods were used to quantitatively assess bird populations, namely total censuses, parcel censuses and punctual indexes of abundance (Ribas and Pons, 2001). The original results by Ribas (1997a, 1997b, concerning the whole area of Montnegre and Corredor) have been adapted by including only those species that used to be present in our study area. ${ }^{\text {(d) }}$ IUCN Red List of Threatened Species (IUCN, 2009); n.a.: species not assessed for the IUCN Red List. ${ }^{(\mathrm{e})}$ Plants: IUCN criteria (1994 version) adapted to Catalonia by Gutiérrez (2004), *considered VU by Sáez and Soriano (2000) according to the same criteria and geographic scale; Birds: IUCN criteria adapted to Catalonia by Estrada et al. (2004); n.e.: no published evaluation is available according to our knowledge.

\section{References:}

Estrada, J., Pedrocchi, V., Brotons, L. et al. (ed), 2004. Atles dels ocells nidificants de Catalunya 1999-2002. Institut Català d'Ornitologia and Lynx, Barcelona. Gutiérrez, C., 2001. Fitxes tècniques del catàleg de flora vascular d'interès conservacionista. Tàxons prioritaris i tàxons d'especial interès. Technical report of the Flora Conservation Scheme. Montnegre-Corredor Park, Vallgorguina. Gutiérrez, C., 2004. Aplicació del Pla de conservació de la flora vascular al Parc del Montnegre i el Corredor. In: IV Trobada d'Estudiosos del Montnegre i el Corredor. Diputació de Barcelona, Barcelona, pp 61-65. IUCN (International Union for Conservation of Nature) 2009. IUCN Red List of Threatened Species. Version 2009.2 www.iucnredlist.org Accessed 29 December 2009. Montserrat, P., [1950] 1989. Flora de la cordillera litoral catalana (porción comprendida entre los ríos Besós y Tordera). Caixa d'estalvis Laietana, Mataró. Pino, J., Rodà, F., Ribas, J. et al., 2000. Landscape structure and bird species richness: implications for conservation in rural areas between natural parks. Landscape and Urban Planning 49, 35-48. Pollard, E., Yates, T., 1993.

Monitoring butterflies for ecology and conservation. Chapman \& Hall, London. Ribas, J. 1997a. Distribució geogràfica dels poblaments avifaunístics hivernals del Montnegre i Corredor. Technical report of the Ecological Monitoring Scheme. MontnegreCorredor Park, Vallgorguina. Ribas, J., 1997b. Atlas parcial dels ocells nidificants del Montnegre i Corredor. Technical report of the Ecological Monitoring Scheme. Montnegre-Corredor Park, Vallgorguina. Ribas, J., Pons, X., 2001. Estudi de la distribució i abundància dels poblaments avifaunístics del Montnegre i el Corredor. In: III Trobada d'Estudiosos del Montnegre i el Corredor. Diputació de Barcelona, Barcelona, pp 35-43. Sáez, L., Soriano, I., 2000. Catàleg de plantes vasculars endèmiques, rares o amenaçades de Catalunya. II. Tàxons no endèmics en situació de risc. Butlletí de la Institució Catalana d'Història Natural 68: 35-50. Stefanescu, C., 2000. El Butterfly Monitoring Scheme en Catalunya: los primeros cinco años. Treballs de la Societat Catalana de Lepidopterologia 15, 3-46. 
Table 2 Relative area of land-uses according to property size for years 1853, 1954, and 2013.

\begin{tabular}{|c|c|c|c|c|c|c|}
\hline & & \multicolumn{5}{|c|}{ Landownership size } \\
\hline & & $<1$ ha & $1-5$ ha & $5-10$ ha & $10-100$ ha & $>100$ ha \\
\hline \multirow{12}{*}{1853} & Holm Oak forest & $2,9 \%$ & $5,0 \%$ & $14,9 \%$ & $46,3 \%$ & $40,7 \%$ \\
\hline & Chestnut forest & $0,5 \%$ & $0,6 \%$ & $1,7 \%$ & $1,6 \%$ & $0,2 \%$ \\
\hline & Riverside forest & $0,3 \%$ & $0,4 \%$ & $0,0 \%$ & $0,6 \%$ & $0,4 \%$ \\
\hline & Pine forest & $0,0 \%$ & $0,1 \%$ & $0,0 \%$ & $2,9 \%$ & $5,7 \%$ \\
\hline & Cork Oak forest & $1,7 \%$ & $1,3 \%$ & $2,7 \%$ & $11,3 \%$ & $10,1 \%$ \\
\hline & Irrigated arable land & $0,0 \%$ & $0,0 \%$ & $0,0 \%$ & $0,5 \%$ & $0,3 \%$ \\
\hline & Rain-fed arable land & $11,3 \%$ & $16,6 \%$ & $9,6 \%$ & $10,6 \%$ & $2,8 \%$ \\
\hline & Vineyard & $68,1 \%$ & $52,8 \%$ & $39,4 \%$ & $4,4 \%$ & $3,3 \%$ \\
\hline & Wasteland for pastures & $15,0 \%$ & $23,0 \%$ & $17,2 \%$ & $21,6 \%$ & $36,4 \%$ \\
\hline & Urban area & $0,2 \%$ & $0,2 \%$ & $0,1 \%$ & $0,1 \%$ & $0,0 \%$ \\
\hline & Unproductive & $0,0 \%$ & $0,0 \%$ & $0,0 \%$ & $0,0 \%$ & $0,0 \%$ \\
\hline & No data & $0,0 \%$ & $0,0 \%$ & $14,4 \%$ & $0,0 \%$ & $0,0 \%$ \\
\hline \multirow{12}{*}{1954} & Holm Oak forest & $9,2 \%$ & $15,2 \%$ & $5,8 \%$ & $30,1 \%$ & $33,4 \%$ \\
\hline & Chestnut forest & $0,9 \%$ & $3,9 \%$ & $0,4 \%$ & $1,3 \%$ & $0,0 \%$ \\
\hline & Riverside forest & $4,9 \%$ & $3,3 \%$ & $1,5 \%$ & $1,2 \%$ & $1,7 \%$ \\
\hline & Pine forest & $20,0 \%$ & $12,9 \%$ & $9,0 \%$ & $8,1 \%$ & $9,5 \%$ \\
\hline & Cork Oak forest & $12,6 \%$ & $15,3 \%$ & $26,3 \%$ & $49,2 \%$ & $47,6 \%$ \\
\hline & Irrigated arable land & $0,2 \%$ & $3,1 \%$ & $0,4 \%$ & $3,0 \%$ & $2,5 \%$ \\
\hline & Rain-fed arable land & $19,1 \%$ & $13,2 \%$ & $21,2 \%$ & $5,3 \%$ & $3,7 \%$ \\
\hline & Vineyard & $27,5 \%$ & $29,8 \%$ & $26,5 \%$ & $1,1 \%$ & $1,0 \%$ \\
\hline & Wasteland for pastures & $5,0 \%$ & $3,2 \%$ & $8,6 \%$ & $0,7 \%$ & $0,6 \%$ \\
\hline & Urban area & $0,7 \%$ & $0,1 \%$ & $0,3 \%$ & $0,1 \%$ & $0,1 \%$ \\
\hline & Unproductive & $0,0 \%$ & $0,0 \%$ & $0,0 \%$ & $0,0 \%$ & $0,0 \%$ \\
\hline & No data & $0,0 \%$ & $0,0 \%$ & $0,0 \%$ & $0,0 \%$ & $0,0 \%$ \\
\hline \multirow{12}{*}{2013} & Holm Oak forest & $28,0 \%$ & $35,3 \%$ & $55,2 \%$ & $31,6 \%$ & $74,0 \%$ \\
\hline & Chestnut forest & $0,0 \%$ & $0,4 \%$ & $0,0 \%$ & $3,1 \%$ & $0,0 \%$ \\
\hline & Riverside forest & $1,3 \%$ & $3,1 \%$ & $0,7 \%$ & $2,6 \%$ & $3,1 \%$ \\
\hline & Pine forest & $15,2 \%$ & $36,5 \%$ & $35,2 \%$ & $15,7 \%$ & $9,0 \%$ \\
\hline & Cork Oak forest & $1,0 \%$ & $7,0 \%$ & $6,4 \%$ & $40,3 \%$ & $11,8 \%$ \\
\hline & Irrigated arable land & $0,8 \%$ & $2,6 \%$ & $0,0 \%$ & $1,0 \%$ & $0,5 \%$ \\
\hline & Rain-fed arable land & $0,1 \%$ & $2,5 \%$ & $0,0 \%$ & $2,2 \%$ & $0,7 \%$ \\
\hline & Vineyard & $0,2 \%$ & $0,6 \%$ & $0,0 \%$ & $0,0 \%$ & $0,0 \%$ \\
\hline & Wasteland for pastures & $0,4 \%$ & $4,0 \%$ & $1,5 \%$ & $2,5 \%$ & $0,5 \%$ \\
\hline & Urban area & $48,3 \%$ & $4,1 \%$ & $0,0 \%$ & $0,1 \%$ & $0,0 \%$ \\
\hline & Unproductive & $4,7 \%$ & $3,9 \%$ & $0,9 \%$ & $0,7 \%$ & $0,4 \%$ \\
\hline & No data & $0,0 \%$ & $0,0 \%$ & $0,0 \%$ & $0,0 \%$ & $0,0 \%$ \\
\hline
\end{tabular}


Table A1 Butterfly assemblages: i) ‘Can Riera de Vilardell’ transect (1994-2005).

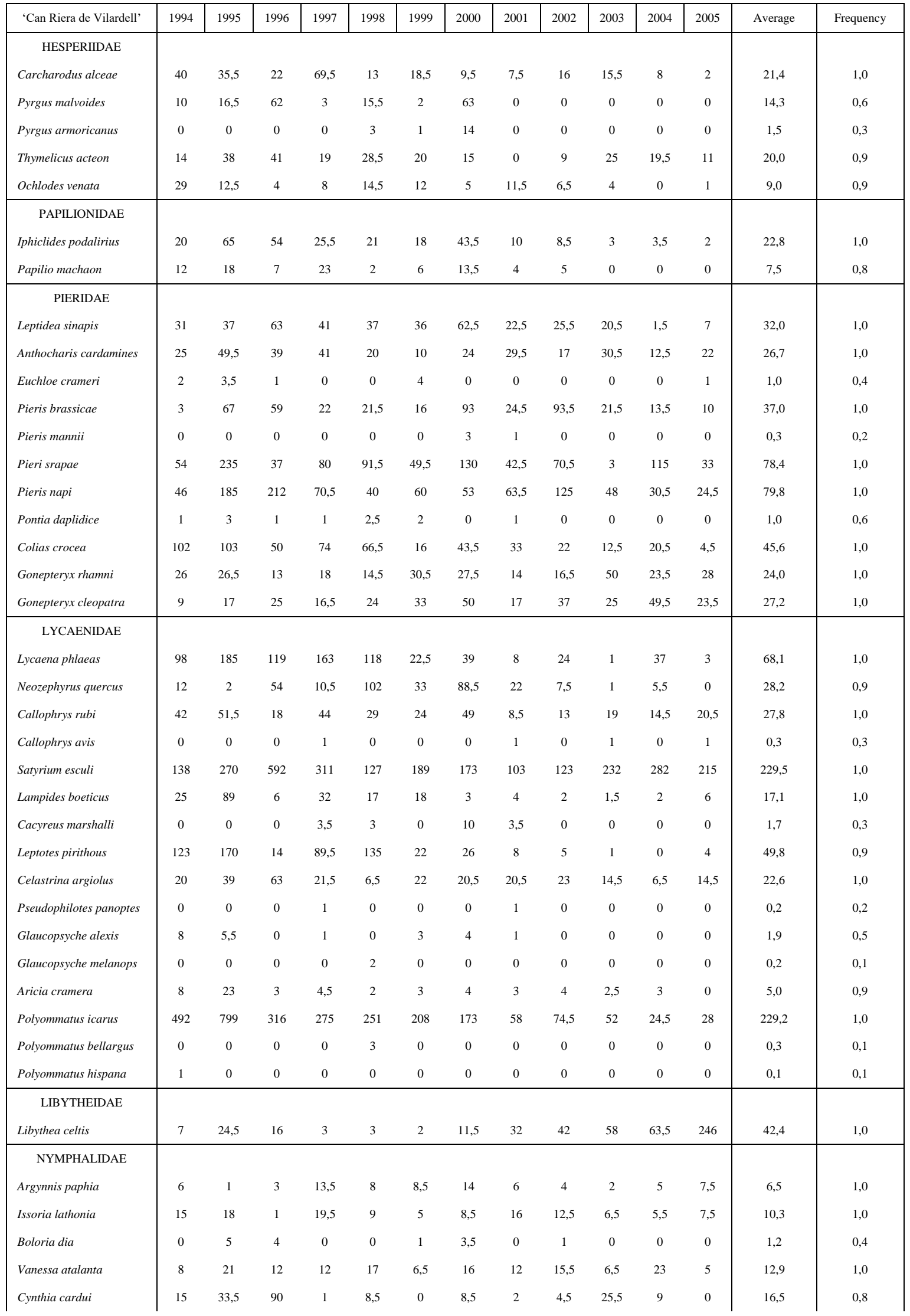




\begin{tabular}{|c|c|c|c|c|c|c|c|c|c|c|c|c|c|c|}
\hline Inachis io & 2 & 3 & 15 & 6,5 & 7,5 & 3 & 3,5 & 1 & 0 & 2,5 & 1 & 1 & 3,8 & 0,9 \\
\hline Aglais urticae & 0 & 0 & 1 & 1 & 0 & 0 & 0 & 1 & 0 & 0 & 0 & 0 & 0,3 & 0,3 \\
\hline Polygonia c-album & 2 & 13 & 20 & 5 & 16,5 & 6 & 42,5 & 9,5 & 15 & 10 & 11,5 & 16 & 13,9 & 1,0 \\
\hline Nymphalis antiopa & 1 & 1 & 3 & 7 & 6 & 7 & 13 & 17 & 30 & 32 & 9 & 32,5 & 13,2 & 1,0 \\
\hline Nymphalis polychloros & 1 & 0 & 2 & 0 & 0 & 2 & 0 & 2 & 2 & 6 & 9 & 14 & 3,2 & 0,7 \\
\hline Euphydryas aurinia & 5 & 0 & 1 & 2 & 1,5 & 6 & 0 & 0 & 1 & 0 & 0 & 2 & 1,5 & 0,6 \\
\hline Melitaea cinxia & 1 & 0 & 0 & 0 & 0 & 0 & 0 & 0 & 0 & 0 & 0 & 0 & 0,1 & 0,1 \\
\hline Melitaea phoebe & 0 & 1 & 1 & 0 & 1,5 & 2 & 0 & 0 & 1 & 0 & 0 & 0 & 0,5 & 0,4 \\
\hline Melitaea didyma & 0 & 0 & 0 & 0 & 0 & 0 & 1 & 0 & 0 & 0 & 0 & 0 & 0,1 & 0,1 \\
\hline Melitaea deione & 1 & 30 & 18 & 6 & 18,5 & 4 & 0 & 0 & 4,5 & 4,5 & 0 & 0 & 7,2 & 0,7 \\
\hline Limenitis camilla & 0 & 0 & 6 & 5 & 3 & 2 & 2 & 0 & 2 & 0 & 0 & 0 & 1,7 & 0,5 \\
\hline Limenitis reducta & 19 & 60,5 & 11 & 5,5 & 14,5 & 22 & 11 & 10 & 10 & 4 & 34 & 8,5 & 17,5 & 1,0 \\
\hline Charaxes jasius & 59 & 58 & 61 & 34,5 & 57 & 69 & 56 & 61,5 & 28,5 & 22 & 38,5 & 15 & 46,7 & 1,0 \\
\hline Apatura ilia & 0 & 0 & 0 & 0 & 3 & 2,5 & 6 & 1 & 0 & 1 & 1,5 & 0 & 1,3 & 0,5 \\
\hline Pararge aegeria & 123 & 250 & 354 & 315 & 179 & 269 & 262 & 211 & 329 & 161 & 148 & 67 & 222,1 & 1,0 \\
\hline Lasiommata megera & 61 & 121 & 12 & 32,5 & 49,5 & 43 & 39,5 & 38 & 62 & 1 & 34 & 10,5 & 42,0 & 1,0 \\
\hline Coenonympha arcania & 4 & 4 & 0 & 0 & 1 & 0 & 0 & 4 & 1 & 0 & 0 & 1 & 1,3 & 0,5 \\
\hline Coenonympha pamphilus & 1 & 0 & 0 & 0 & 0 & 0 & 0 & 0 & 0 & 0 & 0 & 0 & 0,1 & 0,1 \\
\hline Pyronia tithonus & 18 & 22 & 34 & 60 & 54 & 65 & 90 & 16 & 72 & 5 & 6,5 & 0 & 36,9 & 0,9 \\
\hline Pyronia cecilia & 1 & 5 & 0 & 0 & 1 & 0 & 0 & 0 & 1 & 0 & 0 & 0 & 0,7 & 0,3 \\
\hline Pyronia bathseba & 18 & 37 & 11 & 13 & 11 & 42 & 42,5 & 20 & 13 & 32,5 & 29 & 24 & 24,4 & 1,0 \\
\hline Maniola jurtina & 282 & 436 & 629 & 565 & 281 & 424 & 417 & 256 & 212 & 43,5 & 70,5 & 27 & 303,4 & 1,0 \\
\hline Melanargia lachesis & 5 & 4 & 2 & 4 & 0 & 8 & 9,5 & 2 & 0 & 0 & 1 & 0 & 3,0 & 0,7 \\
\hline Hipparchia fagi & 0 & 0 & 2 & 0 & 0 & 0 & 0 & 0 & 0 & 0 & 0 & 0 & 0,2 & 0,1 \\
\hline Hipparchia semele & 0 & 0 & 0 & 0 & 0 & 0 & 0 & 0 & 0 & 0 & 1 & 0 & 0,1 & 0,1 \\
\hline Hipparchia statilinus & 1 & 1 & 7 & 0 & 0 & 0 & 1 & 0 & 0 & 0 & 0 & 0 & 0,8 & 0,3 \\
\hline Hipparchia fidia & 0 & 1 & 0 & 0 & 1 & 4 & 16 & 4,5 & 1 & 0 & 0 & 1 & 2,4 & 0,6 \\
\hline Brintesia circe & 5 & 5 & 5 & 2 & 3 & 19 & 49,5 & 10,5 & 1 & 4 & 4 & 1 & 9,1 & 1,0 \\
\hline Pyrgus sp. & 38 & 123 & 0 & 43 & 36 & 85 & 45 & 3 & 5 & 4 & 2 & 7,5 & 32,6 & 0,9 \\
\hline Gonepteryx sp. & 24 & 34 & 17 & 21,5 & 14,5 & 17 & 24 & 23,5 & 55 & 31 & 40,5 & 51,5 & 29,5 & 1,0 \\
\hline LYCAENIDAE & 0 & 1 & 0 & 0 & 1,5 & 0 & 0 & 0 & 0 & 0 & 1 & 0 & 0,3 & 0,3 \\
\hline Limenitis sp. & 0 & 0 & 0 & 0 & 0 & 0 & 5 & 0 & 0 & 0 & 0 & 0 & 0,4 & 0,1 \\
\hline NYMPHALINAE & 0 & 0 & 0 & 0 & 0 & 1,5 & 0 & 0 & 0 & 0 & 0 & 0 & 0,1 & 0,1 \\
\hline Total ex. & 2114 & 3857 & 3213 & 2646 & 2016 & 2004 & 2438 & 1282 & 1653 & 1046 & 1220 & 1007 & 2041,2 & - \\
\hline Total spp. & 52 & 50 & 51 & 49 & 52 & 51 & 50 & 49 & 46 & 41 & 39 & 39 & 47,4 & - \\
\hline
\end{tabular}

Note: Yearly butterfly counts along transect of 'Can Riera de Vilardell'. Counts include estimated values for missing weeks and therefore correspond to the standardized annual index of relative abundance. 
Table A2 Butterfly assemblages: ii) 'Can Valls d'Olzinelles' transect (2006-2012).

\begin{tabular}{|c|c|c|c|c|c|c|c|c|c|}
\hline 'Can Valls d'Olzinelles' & 2006 & 2007 & 2008 & 2009 & 2010 & 2011 & 2012 & Average & Frequency \\
\hline \multicolumn{10}{|l|}{ HESPERIIDAE } \\
\hline Carcharodus alceae & 3 & 0 & 1 & 0 & 0 & 7 & 5,5 & 2,4 & 0,6 \\
\hline Thymelicus acteon & 3 & 0 & 4 & 0 & 5 & 1 & 6 & 2,7 & 0,7 \\
\hline Ochlodes venata & 5,5 & 14 & 6 & 5,5 & 3 & 6 & 1 & 5,9 & 1,0 \\
\hline \multicolumn{10}{|l|}{ PAPILIONIDAE } \\
\hline Iphiclides podalirius & 5 & 42 & 25,5 & 20,5 & 27 & 22 & 5 & 21,0 & 1,0 \\
\hline Papilio machaon & 0 & 0 & 2 & 0 & 3 & 1 & 0 & 0,9 & 0,4 \\
\hline \multicolumn{10}{|l|}{ PIERIDAE } \\
\hline Leptidea sinapis & 6 & 3 & 13,5 & 5 & 6 & 14,5 & 8,5 & 8,1 & 1,0 \\
\hline Anthocharis cardamines & 13 & 6 & 18,5 & 39 & 31 & 44,5 & 35 & 26,7 & 1,0 \\
\hline Euchloe crameri & 0 & 0 & 0 & 1 & 0 & 0 & 0 & 0,1 & 0,1 \\
\hline Aporia crataegi & 0 & 0 & 0 & 0 & 1 & 0 & 0 & 0,1 & 0,1 \\
\hline Pieris brassicae & 20 & 30 & 20,5 & 36,5 & 13,5 & 37 & 16 & 24,8 & 1,0 \\
\hline Pieris rapae & 18,5 & 23 & 56 & 15 & 75,5 & 127 & 77 & 56,0 & 1,0 \\
\hline Pieris napi & 24,5 & 103 & 22 & 22 & 22 & 164 & 29 & 55,1 & 1,0 \\
\hline Pontia daplidice & 1 & 0 & 0 & 0 & 0 & 0 & 0 & 0,1 & 0,1 \\
\hline Colias crocea & 31,5 & 17 & 18 & 50,5 & 28,5 & 21 & 32,5 & 28,4 & 1,0 \\
\hline Gonepteryx rhamni & 20 & 23 & 13,5 & 16 & 18 & 26 & 19 & 19,4 & 1,0 \\
\hline Gonepteryx cleopatra & 11,5 & 6 & 7 & 9 & 4,5 & 11 & 3 & 7,4 & 1,0 \\
\hline \multicolumn{10}{|l|}{ LYCAENIDAE } \\
\hline Lycaena phlaeas & 23,5 & 23,5 & 22,5 & 3 & 35 & 34 & 33,5 & 25,0 & 1,0 \\
\hline Thecla betulae & 0 & 0 & 0 & 1 & 0 & 0 & 0 & 0,1 & 0,1 \\
\hline Neozephyrus quercus & 0 & 0 & 0 & 11 & 0 & 34,5 & 1 & 6,6 & 0,4 \\
\hline Callophrys rubi & 7 & 7 & 0 & 0 & 1,5 & 9,5 & 8 & 4,7 & 0,7 \\
\hline Satyrium w-album & 0 & 0 & 1,5 & 0 & 0 & 0 & 0 & 0,2 & 0,1 \\
\hline Satyrium esculi & 111 & 155 & 107 & 128 & 328 & 240 & 182 & 178,6 & 1,0 \\
\hline Lampides boeticus & 10 & 2 & 0 & 2,5 & 0 & 0 & 6,5 & 3,0 & 0,6 \\
\hline Cacyreus marshalli & 1 & 0 & 0 & 0 & 0 & 0 & 0 & 0,1 & 0,1 \\
\hline Leptotes pirithous & 0 & 11 & 0 & 1,5 & 0 & 9 & 1 & 3,2 & 0,6 \\
\hline Celastrina argiolus & 5 & 50,5 & 32 & 6,5 & 16 & 9,5 & 13 & 18,9 & 1,0 \\
\hline Glaucopsyche alexis & 0 & 0 & 1,5 & 2,5 & 1 & 0 & 0 & 0,7 & 0,4 \\
\hline Aricia cramera & 0 & 0 & 0 & 0 & 5 & 1 & 0 & 0,9 & 0,3 \\
\hline Polyommatus icarus & 44 & 16 & 33 & 28 & 29,5 & 30,5 & 11,5 & 27,5 & 1,0 \\
\hline \multicolumn{10}{|l|}{ LIBYTHEIDAE } \\
\hline Libythea celtis & 12 & 17 & 19 & 14 & 13 & 17,5 & 11 & 14,8 & 1,0 \\
\hline \multicolumn{10}{|l|}{ NYMPHALIDAE } \\
\hline Argynnis paphia & 9,5 & 20,5 & 45 & 28,5 & 31 & 26 & 10 & 24,4 & 1,0 \\
\hline Issoria lathonia & 0 & 4 & 5 & 6,5 & 2 & 4 & 1 & 3,2 & 0,9 \\
\hline Vanessa atalanta & 17 & 10 & 14 & 11 & 16 & 8,5 & 7 & 11,9 & 1,0 \\
\hline Cynthia cardui & 18 & 1 & 1 & 91,5 & 4 & 1 & 3 & 17,1 & 1,0 \\
\hline Inachis io & 0 & 0 & 7 & 13,5 & 15 & 35,5 & 11 & 11,7 & 0,7 \\
\hline Polygonia c-album & 19,5 & 20 & 32 & 14,5 & 19,5 & 28,5 & 10 & 20,6 & 1,0 \\
\hline Nymphalis antiopa & 11 & 4 & 6 & 2 & 0 & 4 & 7 & 4,9 & 0,9 \\
\hline Nymphalis polychloros & 5 & 1 & 0 & 3 & 4 & 2 & 7 & 3,1 & 0,9 \\
\hline Euphydryas aurinia & 0 & 0 & 0 & 0 & 1 & 0 & 0 & 0,1 & 0,1 \\
\hline Melitaea phoebe & 3 & 0 & 0 & 0 & 0 & 2 & 0 & 0,7 & 0,3 \\
\hline
\end{tabular}




\begin{tabular}{|l|ccccccc|c|c|} 
Melitaea deione & 6,5 & 9 & 2 & 1,5 & 2 & 20,5 & 15 & 8,1 & 1,0 \\
Limenitis camilla & 4 & 2 & 10 & 7 & 4 & 6 & 4 & 5,3 & 1,0 \\
Limenitis reducta & 2,5 & 17,5 & 2 & 4 & 10 & 3 & 1 & 5,7 & 1,0 \\
Charaxes jasius & 5 & 3 & 3,5 & 9 & 0 & 8 & 2,5 & 4,4 & 0,9 \\
Apatura ilia & 5 & 1 & 0 & 5 & 4,5 & 11 & 1 & 3,9 & 0,9 \\
Pararge aegeria & 275 & 270 & 119 & 86,5 & 57 & 162 & 63 & 147,4 & 1,0 \\
Lasiommata megera & 8 & 8 & 6 & 9 & 11 & 21,5 & 8,5 & 10,3 & 1,0 \\
Coenonympha arcania & 6,5 & 7 & 0 & 0 & 0 & 1 & 0 & 2,1 & 0,4 \\
Pyronia tithonus & 0 & 0 & 1 & 0 & 0 & 0 & 0 & 0,1 & 0,1 \\
Pyronia cecilia & 1 & 0 & 0 & 9 & 0 & 0 & 0 & 1,4 & 0,3 \\
Pyronia bathseba & 4,5 & 0 & 0 & 1,5 & 3 & 6 & 4 & 2,7 & 0,7 \\
Maniola jurtina & 11 & 13 & 9 & 23 & 16 & 48,5 & 17 & 19,6 & 1,0 \\
Hipparchia statilinus & 1 & 0 & 0 & 0 & 0 & 0 & 0 & 0,1 & 0,1 \\
Hipparchia fidia & 0 & 0 & 0 & 1 & 0 & 0 & 0 & 0,1 & 0,1 \\
Brintesia circe & 1 & 0 & 0 & 6,5 & 1 & 0 & 1 & 1,4 & 0,6 \\
Pyrgus sp. & 3 & 1 & 0 & 0 & 2 & 4,5 & 1 & 1,6 & 0,7 \\
Pieris sp. & 0 & 0 & 0 & 23,5 & 0 & 0 & 0 & 3,4 & 0,1 \\
Gonepteryx sp. & 6 & 11 & 13,5 & 8 & 12 & 13,5 & 11 & 10,7 & 1,0 \\
\hline \multicolumn{1}{|c|}{ PIERIDAE } & 0 & 1 & 0 & 0 & 0 & 0 & 0 & 0,1 & 0,1 \\
Limenitis sp. & 0 & 0 & 0 & 1 & 0 & 0 & 2 & 0,4 & 0,3 \\
\hline Total ex. & 799 & 952 & 700 & 784 & 882 & 1283 & 692 & 870,2 & - \\
Total spp. & 34 & 35 & 41 & 38 & 41 & 39 & 38,4 & - \\
\hline
\end{tabular}

Note: Yearly butterfly counts along transect of 'Can Valls d'Olzinelles'. Counts include estimated values for missing weeks and therefore correspond to the standardized annual index of relative abundance. 
Figure 1 Study area within Europe, Catalonia and the Barcelona Metropolitan Region.
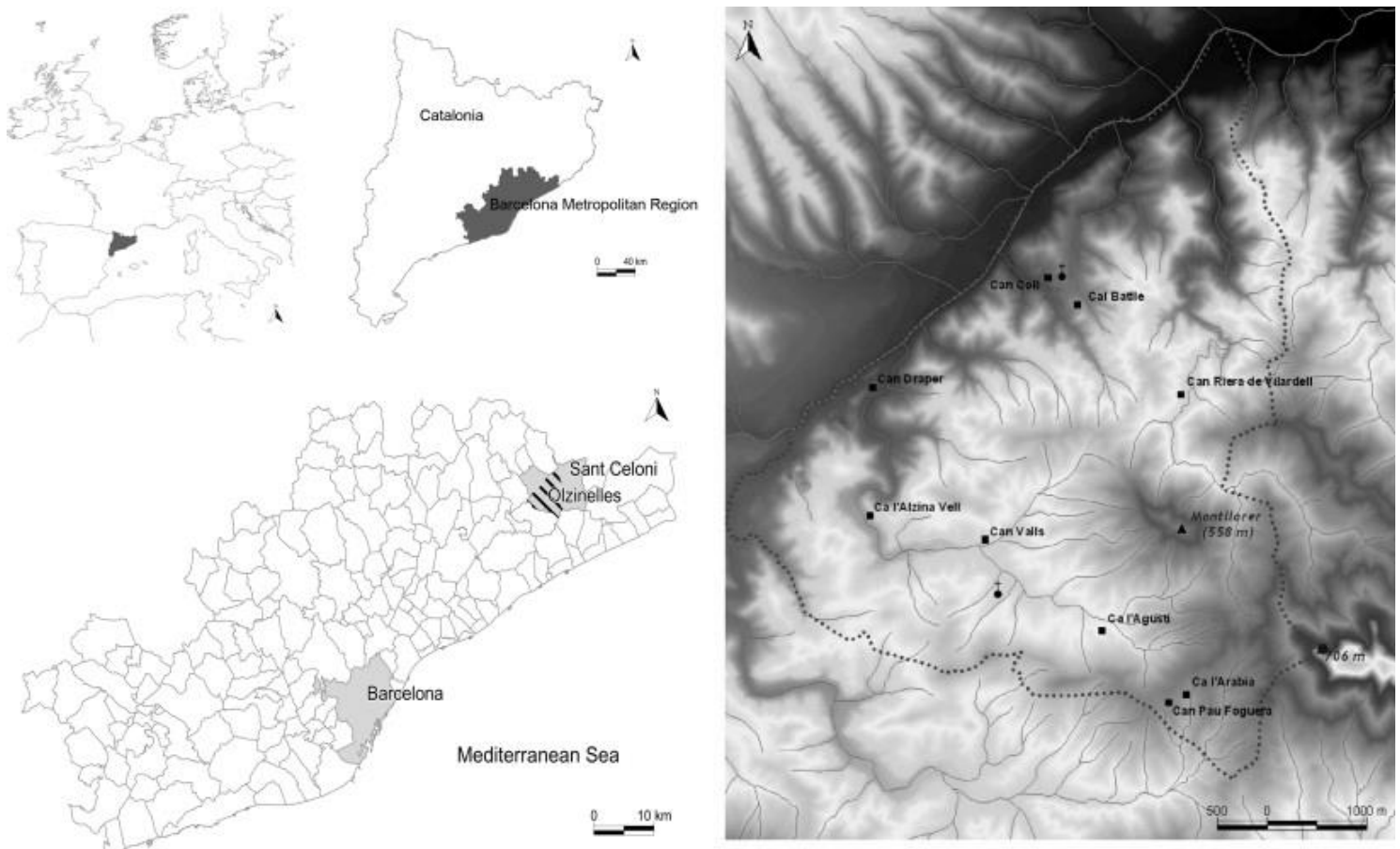
Figure 2 Land-cover maps for 1850s, 1956 and 2012.
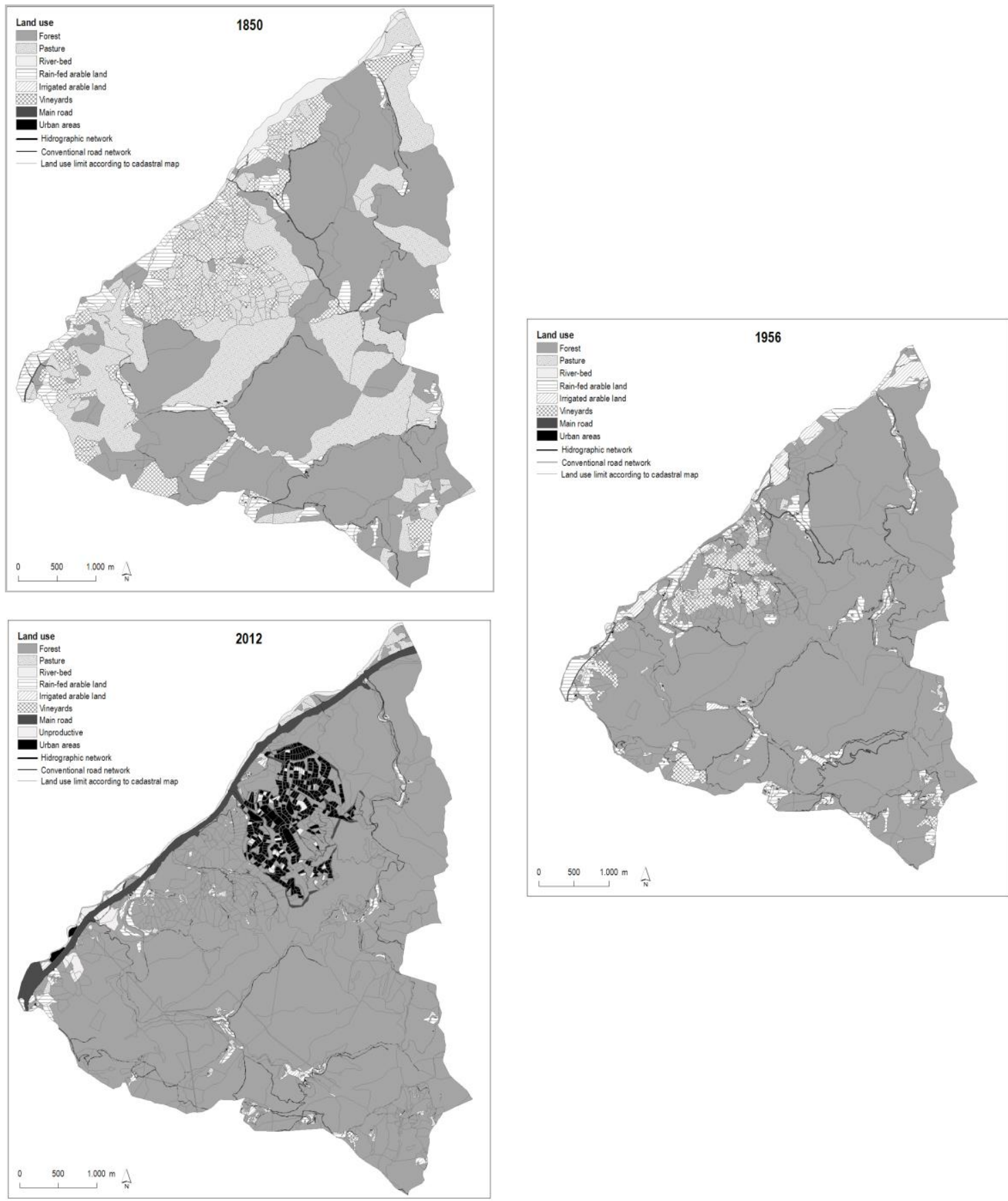
Figure 3 Shannon-Wiener Index (H) and Effective Mesh Size (MESH) for 1850s, 1956 and 2012.

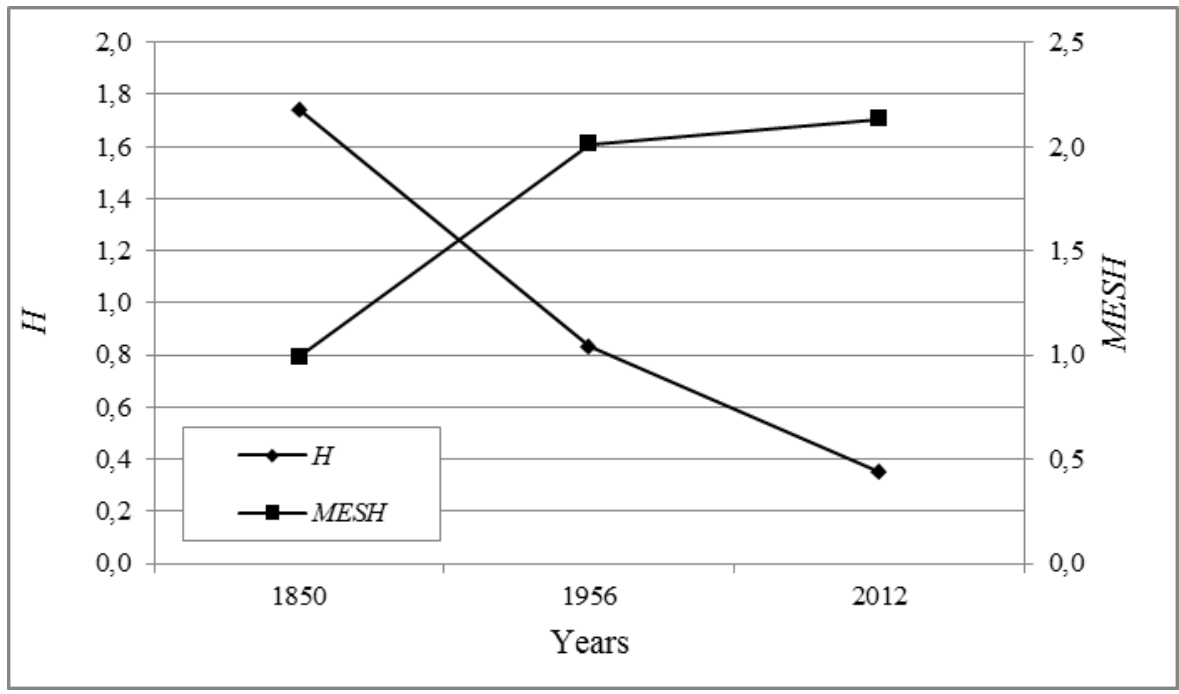


Figure 4 Absolute Ecological Connectivity Index $\left(E C I_{a}\right)$ for 1850s, 1950s and 2012.

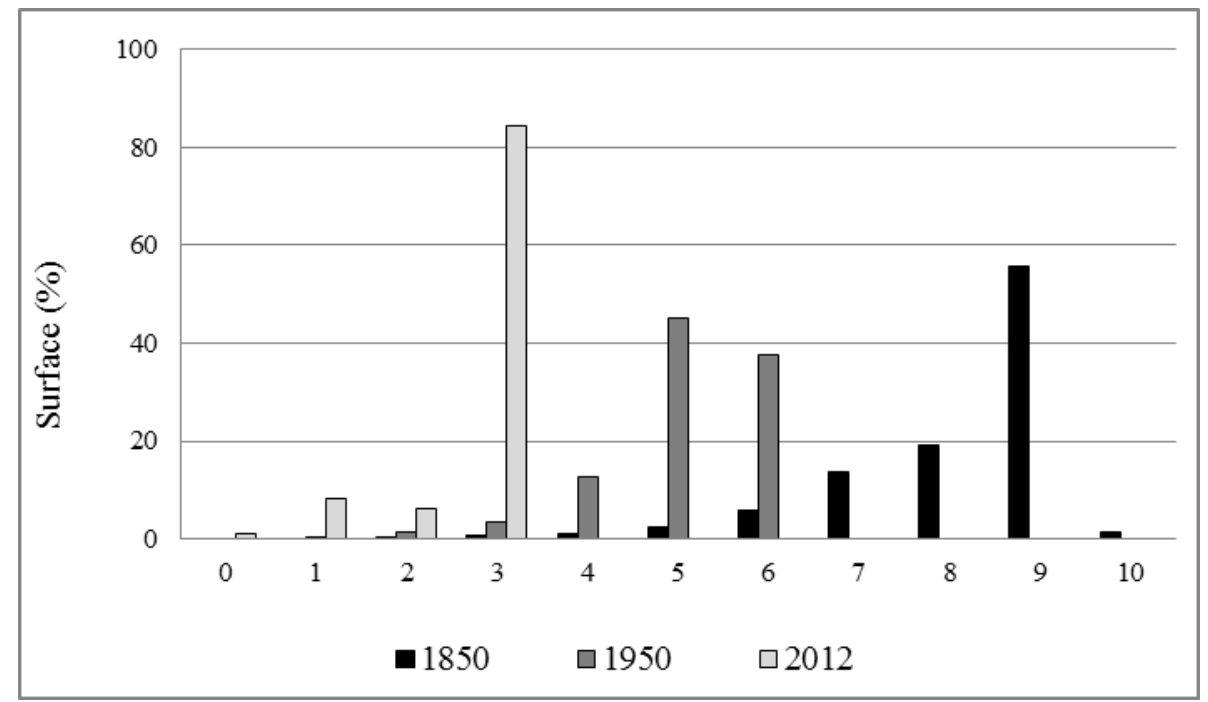


Figure 5 Butterfly species richness and abundance in 'Can Riera de Vilardell' (1994-2005) and 'Can Valls d'Olzinelles' (2006-2012) transects.

'Can Riera de Vilardell' transect

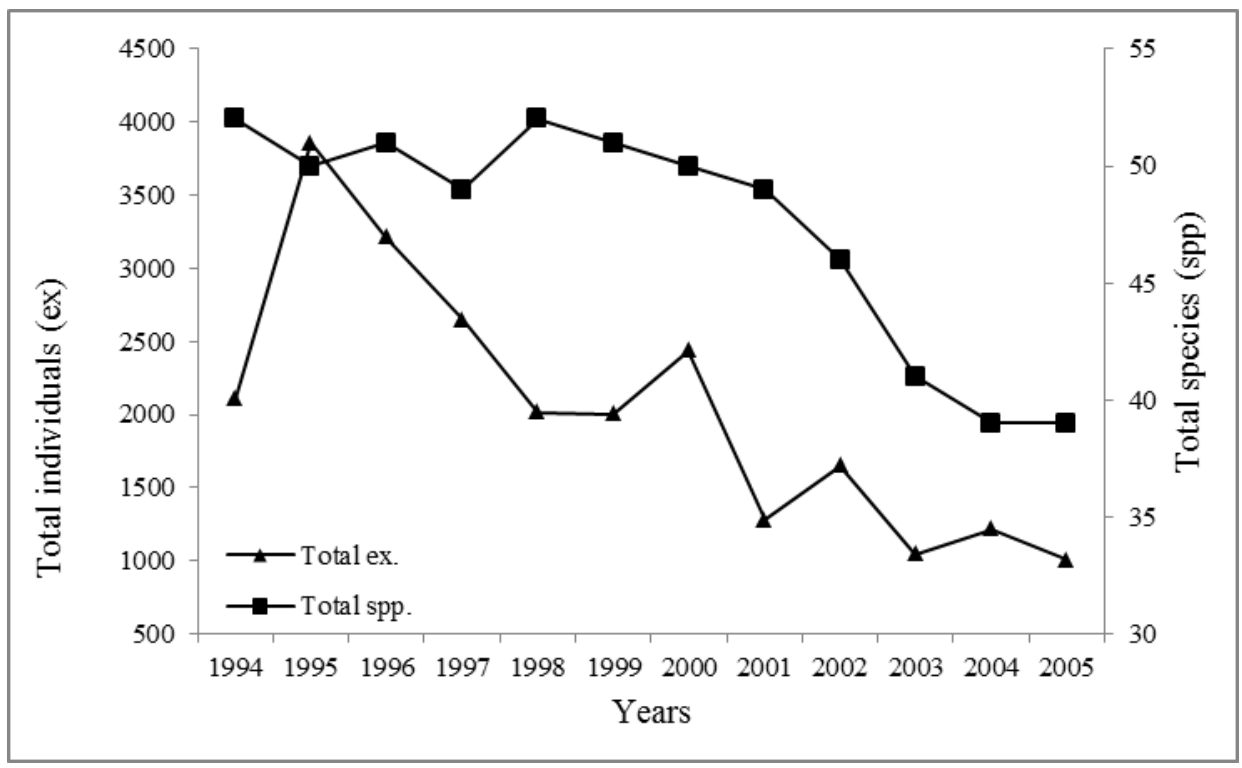

'Can Valls d'Olzinelles' transect

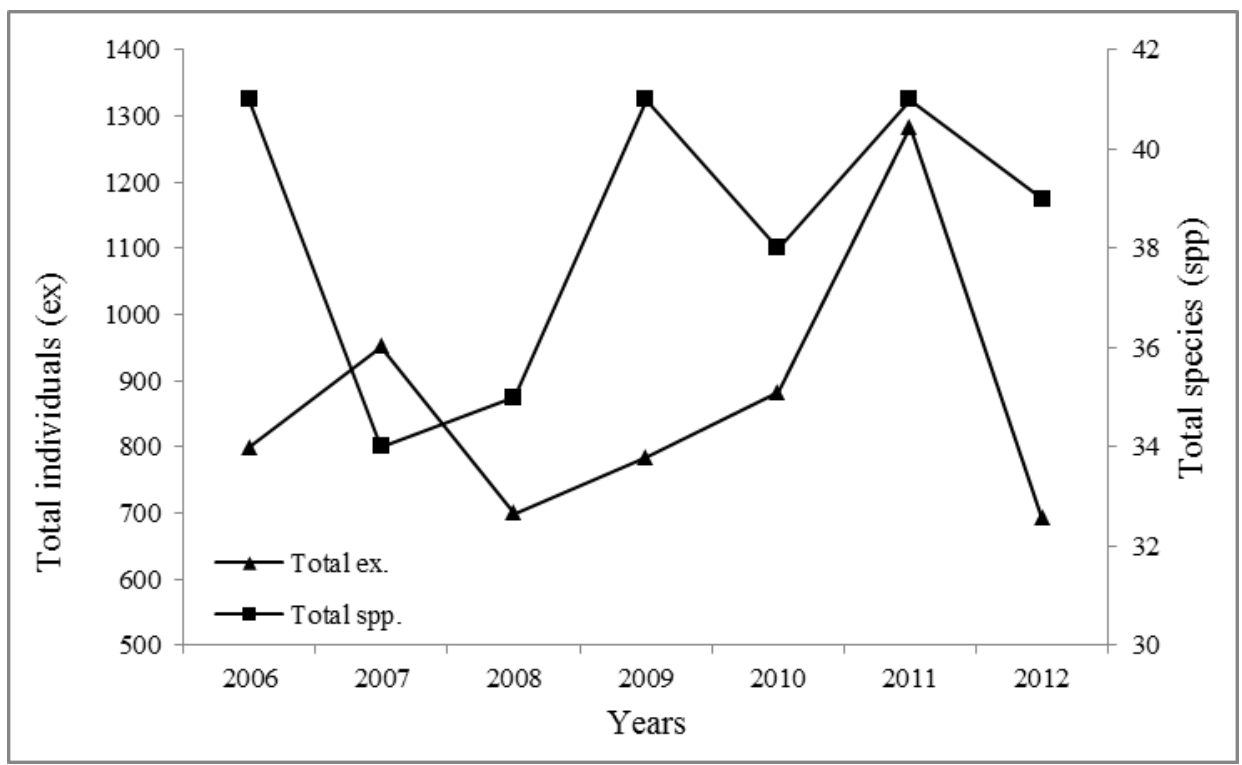


Figure 6 Changes along time in the proportion of butterflies preferring open habitats in 'Can Riera de Vilardell' (1994-2005) and 'Can Valls d'Olzinelles' (2006-2012) transects.

'Can Riera de Vilardell' transect

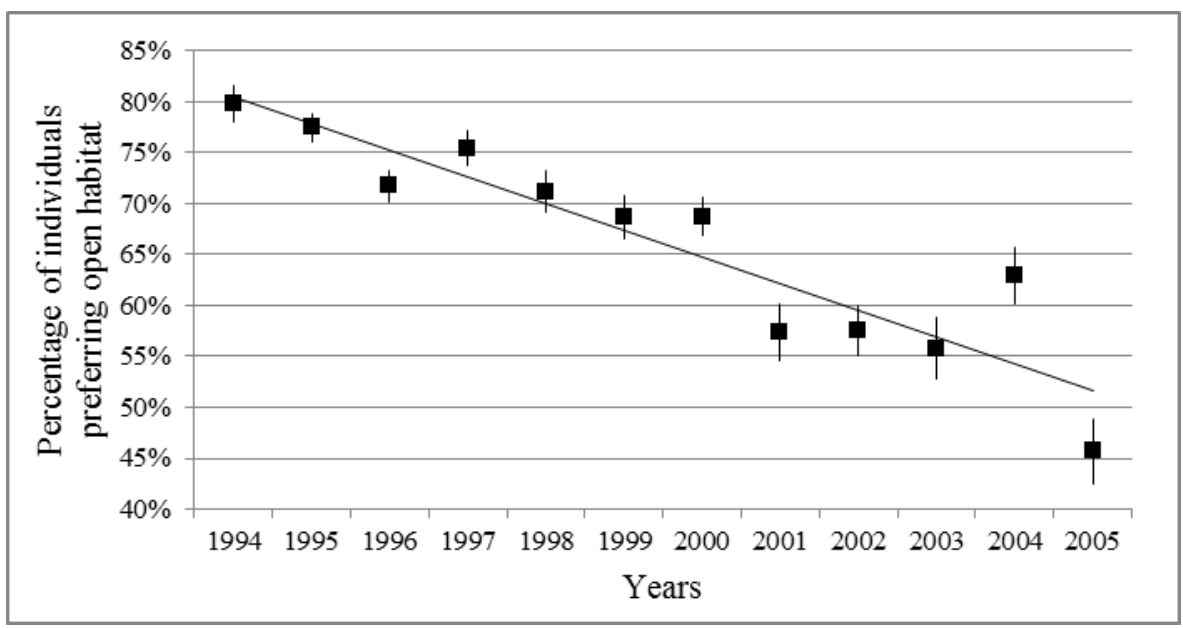

\section{'Can Valls d'Olzinelles' transect}

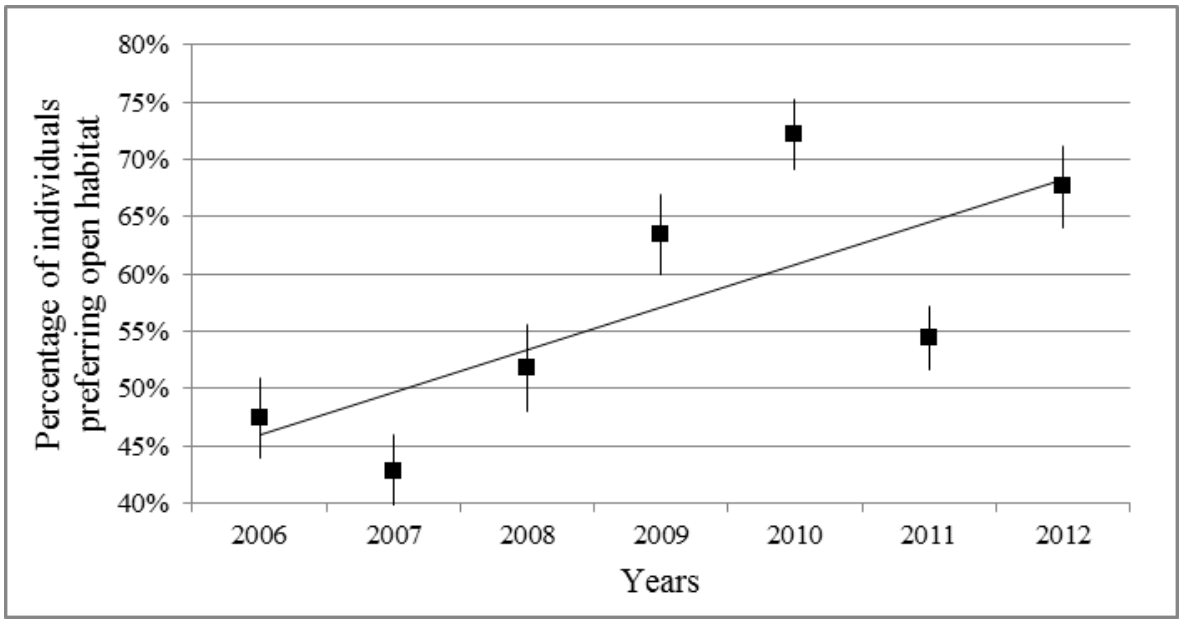

Note: Each butterfly species was classified as either preferring 'open habitats' or 'closed habitats' (forest), based on data of the whole CBMS network (see text for details). For each year, a proportion was calculated for the sum of individuals of species preferring open habitats with respect to all the individuals that were counted that year. Error bars show 95\% CI (confidence interval). 


\section{Annex}

Figure A1 Basic Ecological Connectivity Index (ECI $I_{b 1}$-forest, $E C I_{b 2}$-agriculture, $E C I_{b 3}$-pasture) for 1850s, 1950s and 2012.
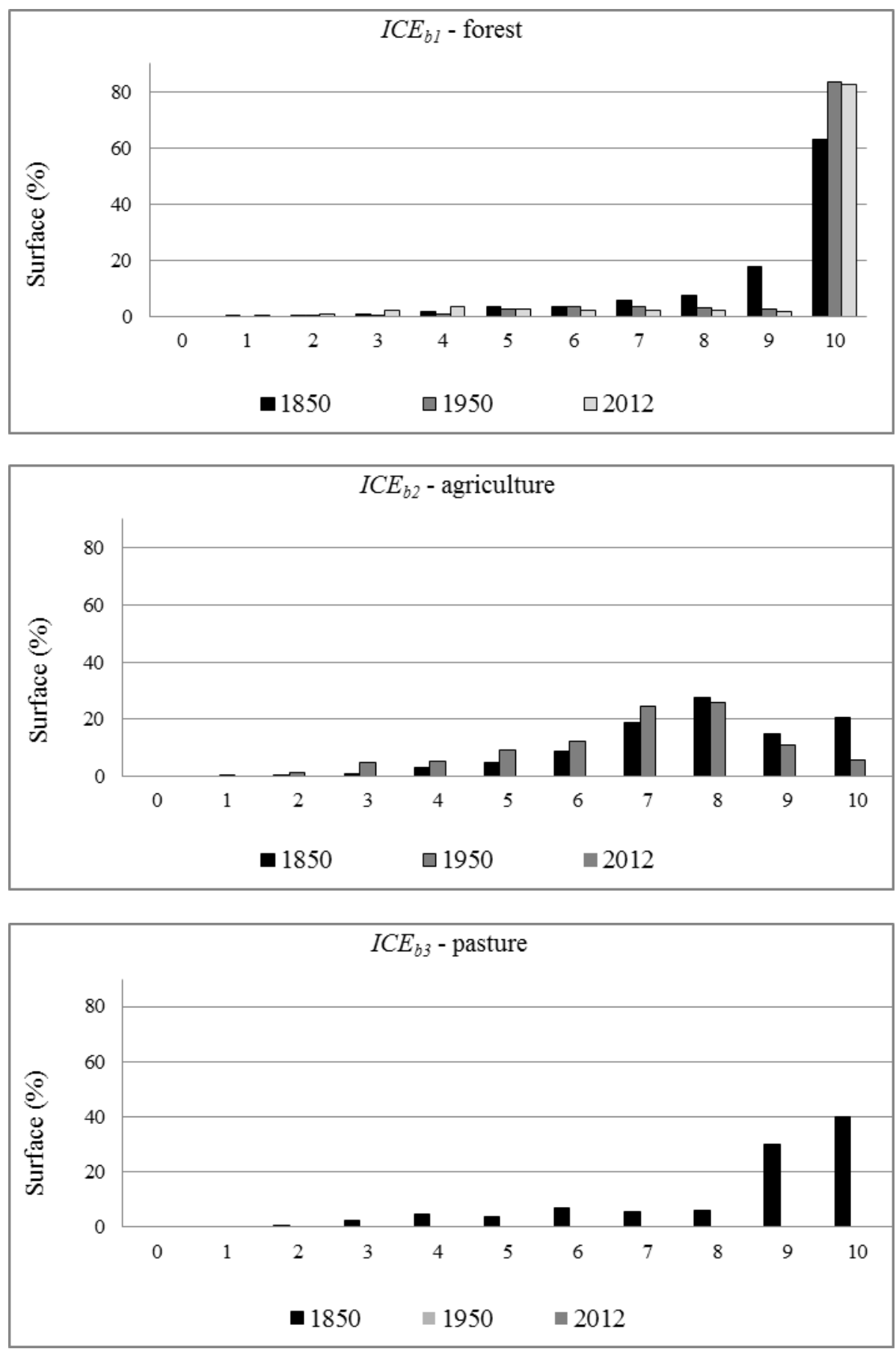